\title{
Financialization revisited: the economics and political economy of the vampire squid economy
}

\author{
Thomas Palley* \\ Independent analyst, Washington, DC, USA
}

This paper explores the economics and political economy of financialization using Matt Taibbi's vampire squid metaphor to characterize it. The paper makes five innovations. First, it focuses on the mechanics of the 'vampire squid' process whereby financialization rotates through the economy, loading sector balance sheets with debt. Second, it identifies the critical role of government budget deficits for the financialization process. Third, it identifies the critical role of central banks, which are the lynchpin of the system and now serve as de facto guarantors of the value and liquidity of private sector liabilities. Fourth, the paper argues financialization imposes a form of policy lock-in. Fifth, it argues financialization transforms popular attitudes and understandings, thereby generating political support despite poor economic outcomes. In effect, there is a politics of financialization that goes hand-in-hand with the economics. The paper concludes with some observations on why mainstream macroeconomics has no equivalent construct to financialization and discusses the disquieting unexplored terrain that the economy is now in.

Keywords: financialization, debt, budget deficits, central banks, lock-in

JEL codes: $E 10, E 44, E 58, G 18$

\section{INTRODUCTION: THE VAMPIRE SQUID ECONOMY}

'The first thing you need to know about Goldman Sachs is that it is everywhere. The world's most powerful investment bank is a great vampire squid wrapped around the face of humanity, relentlessly jamming its blood funnel into anything that smells like money.'

Matt Taibbi (Rolling Stone, 5 April 2010, p. 1)

This paper explores the economics and political economy of financialization using Matt Taibbi's evocative vampire squid metaphor to characterize it. The paper makes five innovations. First, it focuses on the mechanics of the 'vampire squid' process whereby financialization rotates through the economy consuming sector balance sheets. It does so by loading sector balance sheets with debt. That applies to all sectors (household, non-financial corporate, financial, and government). Indeed, in its latest iteration, financialization has now moved on to consume central bank balance sheets, with central banks massively expanding their liability issuance (that is, bank reserves).

* Email: mail@thomaspalley.com. My thanks to Esteban Pérez Caldentey for some helpful suggestions. The usual disclaimers apply. 
Second, government budget deficits have been critical and central to the financialization process. They have helped sustain the process and have been a source of major financial gain for financial interests.

Third, the paper identifies the critical role of central banks, especially the Federal Reserve. Central banks are the lynchpin of the system, and they now serve as de facto guarantors of the value and liquidity of private sector liabilities. Absent their support, the economic system would likely have crashed long ago in a 1929-styled Great Depression.

Fourth, the paper argues financialization imposes a form of policy lock-in. The high levels of debt with which it saddles sector balance constitute a barrier to changing the system. That is because change would undermine the value of that debt, potentially triggering hugely damaging financial and economic crisis.

Fifth, the paper argues financialization transforms popular attitudes and understandings. That generates political support for it, which is part of explaining its longevity despite poor economic outcomes. In effect, there is a politics of financialization that goes hand-in-hand with the economics. The paper concludes with some observations on why mainstream macroeconomics has no equivalent construct to financialization, and discusses the disquieting unexplored terrain that the economy is now in.

\section{FINANCIALIZATION REVISITED}

In recent years there has been an explosion in the literature on financialization, much of which is empirical in focus. That empirical literature aims to document the stylized facts of financialization and econometrically identify financialization's impact on macroeconomic outcomes. This section briefly reviews and comments on some of that research, the purpose being to provide context for the overall paper.

Figure 1 provides a taxonomy of the main dimensions of research on financialization. It is a slightly more elaborated breakdown of the categories provided by Epstein (2015) in his insightful and amusingly titled survey paper, 'Financialization: there's something happening here.' The discussion of the categories also draws on the excellent paper by Kohler et al. (2019).

\subsection{Definitions}

The first column in Figure 1 concerns the definitions of financialization. Krippner (2005, p. 174), who was early to identify the financialization phenomenon, defines it as 'a pattern of accumulation in which profits accrue primarily through financial channels rather than through trade and commodity production.' Epstein (2004, p. 3), who was also early to recognize the significance of financialization, defines it as "the increasing role of financial motives, financial markets, financial actors and financial institutions in the operation of the domestic and international economies.'

Both those definitions are primarily economic. Palley (2013, p. 1) provides an alternative political economic definition whereby 'financialization corresponds to financial neoliberalism which is characterized by the domination of the macro economy and economic policy by financial sector interests.' That definition blends financialization with Neoliberalism, and it explicitly introduces politics via emphasis of interests 


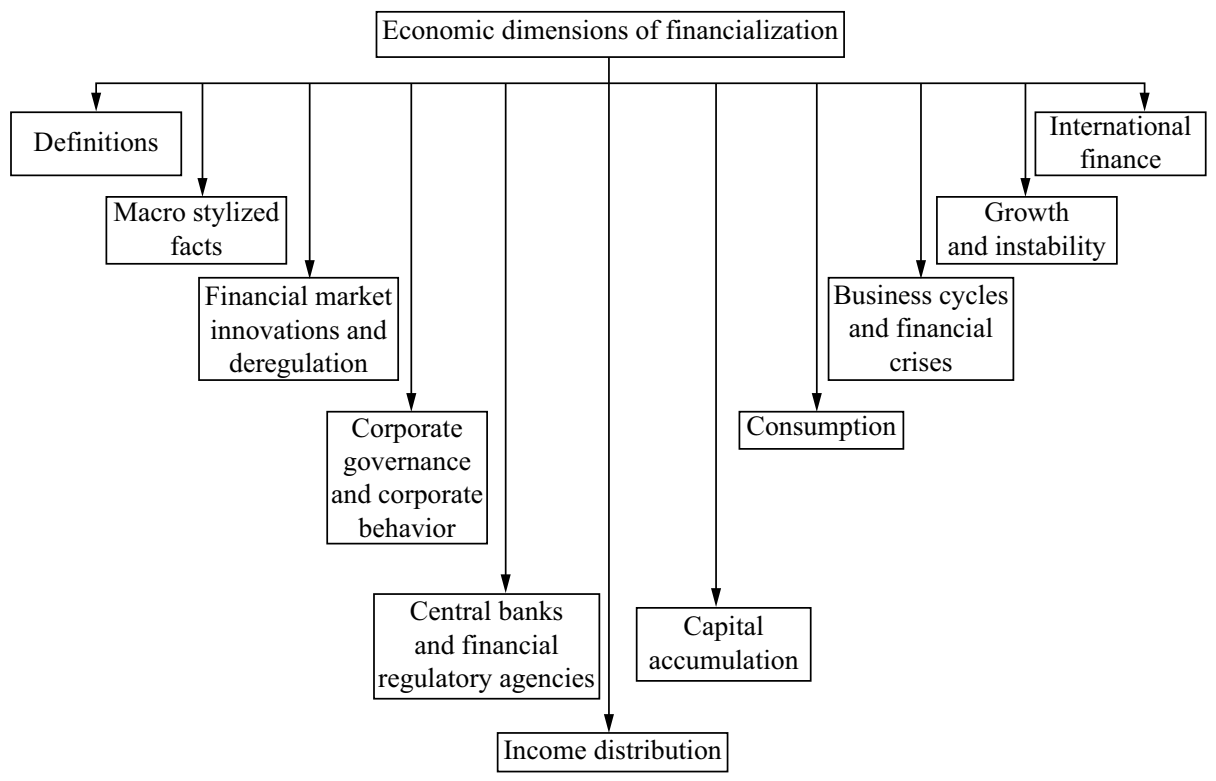

Figure 1 A taxonomy of major issues addressed in the financialization economics literature

and policy. Analytically, it identifies financialization with the period 1980-today, which distances it from the history of financial deepening and increased financial sophistication. ${ }^{1}$

Financialization is not synonymous with the history of finance. Instead, it refers to the political and economic dominance of finance within the Neoliberal regime, plus the functional significance of finance for the regime. However, separating financialization from financial deepening and financial innovation is analytically tricky. That is because financialization promotes financial deepening and innovation as that is the way finance gets to reorient the economic process through the financial sector, change the structure of balance sheets, and claim a greater share of GDP.

The important feature is that those developments are strongly influenced by policy and politics. They happen because they are assisted by policy and (as shown below) they require a new supportive policy regime. Without that regime, the system is unsustainable. In other words, much of the financial deepening and innovation would fail the 'market' test, in the sense of being unable to sustain itself.

There is also an 'ad hoc' dimension to those developments, particularly as regards the need for policy to support the system. Parts of the financialization phenomenon are the result of design, but the parts regarding central bank support activities are

1. Graebner (2011) has shown civilization is marked by the increased use and presence of finance. Prompted by that, Sawyer (2013, p. 6, cited in Epstein 2015, p. 5) asks whether financialization has been ongoing throughout most of the history of civilization. This paper would definitively answer 'No' to that question. 
improvised responses to emergent crises. Proponents of financial Neoliberalism did not intend to create an unstable stagnationist economy, but that is what they have done. $^{2}$

Epstein (2015, p. 5) observes that financialization and Neoliberalism have arisen simultaneously, which makes disentangling their impacts difficult. That said, it is important to analytically understand the contributions of each. Financialization represents both an extension and a transformation of Neoliberalism. Neoliberal reasoning is used to make the case for deregulation of financial markets, and financial interests are supportive of Neoliberal policy in the broader economy. Those developments make financialization an amplifying extension of Neoliberalism.

However, on top of that, financialization transforms Neoliberalism. In particular, it fills the aggregate demand (AD) gap created by Neoliberalism. As observed by Palley (2013, p. 6): 'The neoliberal model undermined the income and demand generation process by shifting income from wages to profit and by widening wage inequality. That created a growing structural AD gap, and the role of finance was to fill that gap.' That filling is accomplished by borrowing and asset price inflation, both of which are facilitated by financial market deregulation. Filling the demand gap also leads to the creation of a new business cycle (Palley 2005) in which central banks become the guarantors of the system, and that guarantee is exercised by underwriting and inflating financial asset values - about which more later.

The important point is those developments are fundamental transformations of Neoliberalism. Having invoked Neoliberalism's laissez-faire 'small' government philosophy to justify financial deregulation, financialization has actually produced a system in which 'big' government (that is, the fiscal authority and central bank) plays a pivotal role. That role is to underwrite and inflate financial asset prices. It is necessary because the system is unstable and exhibits proclivities to periodic crisis and stagnation. It is a role that is fundamentally counter to Neoliberalism's claims about market economies.

Marxist economics offers another definitional perspective whereby financialization is an economic innovation for capturing surplus. Lysandrou (2017) argues debt is a way of capturing future surplus, as if the system were colonizing the future. ${ }^{3}$ Lapavitsas (2009) represents financialization as capturing surplus via the injection of finance into an array of activities. That can involve creation of new lending markets, such as the sub-prime mortgage market. It also connects closely with Neoliberal privatization whereby the state has stepped back from provision, transferring the activity to private providers who finance and operate the activities according to financial sector criteria. Those margins of extension are illustrative of the invasiveness of financialization. They are also consistent with financialization as an extension and transformation of Neoliberalism since privatization is a pillar of Neoliberalism.

Lastly, financialization can be contrasted with Minsky's construct of 'money manager capitalism' (Minsky 1992a), which has been emphasized by Wray (2009). Minsky emphasizes both the endogenous instability of finance and the different allocation

2. Proponents of financial Neoliberalism (see for example Posen 2007) viewed financial market developments as stabilizing the system via diversification and pooling of risk, and also improving the efficiency of credit allocation. Their analytical failure reflects a failure to understand financial market developments as part of a systemic macroeconomic development, which in its entirety was unstable and stagnationist.

3. A Keynesian perspective would characterize debt as borrowing demand from the future. Borrowing (that is, new debt) adds to AD today, but becomes a burden on $\mathrm{AD}$ tomorrow (Palley 1994). 
criteria of money manager capitalism compared to managerial capitalism. Those features are certainly consistent with a financialization perspective and can (and should) be incorporated within the narrative. However, Minsky's money manager capitalism is not synonymous with financialization in three important ways (Palley 2010a). First, it misses financialization's Neoliberal dimension aimed at weakening labor and increasing the profit share. Second, Minsky views endogenous instability as arising from changing psychological proclivities induced by financial tranquility. That differs from the financialization hypothesis which views instability as arising from the growing $\mathrm{AD}$ gap created by income redistribution and the income transfer associated with servicing debt. Third, Minsky focused on business debt and neglected the role of household borrowing and household debt.

\subsection{Theorizing financialization: a simple diagrammatic model}

One of the difficulties of addressing financialization is its extensive, complex, and farreaching effects. It enters the economic system through multiple points, and its impacts then ramify via multiple interacting channels. Mathematical models attempt to capture those processes through systems of simultaneous equations which embody the behaviors of economic agents.

Figure 2 provides a diagrammatic model of financialization that is an elaboration of that contained in Palley $(2007 ; 2013$, p. 30). It dovetails with Figure 1, showing how the strands of the literature identified in Figure 1 fit into the overarching analysis. The outer rectangle represents the socioeconomic system, and financialization takes place within that system. As part of that, it can transform the system by transforming values and understandings. That has important political implications which are touched upon in Section 8. Figure 2 shows a cascade of effects running from left to right. However, in order to keep the diagram simple, it does not show feedback effects from 'economic outcomes' back into the cascade of effects. Those feedbacks are critical for determining equilibrium outcomes, and they can also be the cause of instability.

There are many things to note. First, financialization has been powered by financial interests pursuing their own advantage, and that pursuit includes working to change policy. That renders it an intrinsically political phenomenon. The extraordinary bipartisan political power of Goldman Sachs in Washington DC, which encompasses both the Treasury and Federal Reserve, is public knowledge. Citigroup is another bank with enormous political clout, exemplified by its alumni former Treasury Secretary Robert Rubin and former IMF First Deputy Managing Director Stanley Fischer. Less appreciated is the power of the world's largest asset manager Blackrock (Ungarino 2021) and private equity firm Carlyle Group. These, and other actors like the McKinsey Group, are so visibly powerful that they warrant concrete spotlighting in this theoretical segment of the paper.

Second, financialization enters through multiple points: via financial market innovation and deregulation; via changed corporate behavior; via other economic policies (for example, globalization, privatization, labor market deregulation, etc.) which financial interests lobby for; and via changed central bank policies.

Consideration of those entry points is revealing. Financial interests advocate for Neoliberal economic policies, which is why financialization amplifies Neoliberalism and is joined at the hip with it. Economic policies also need to be separated out. Figure 2 distinguishes between financial deregulation, other economic policies, and central bank 


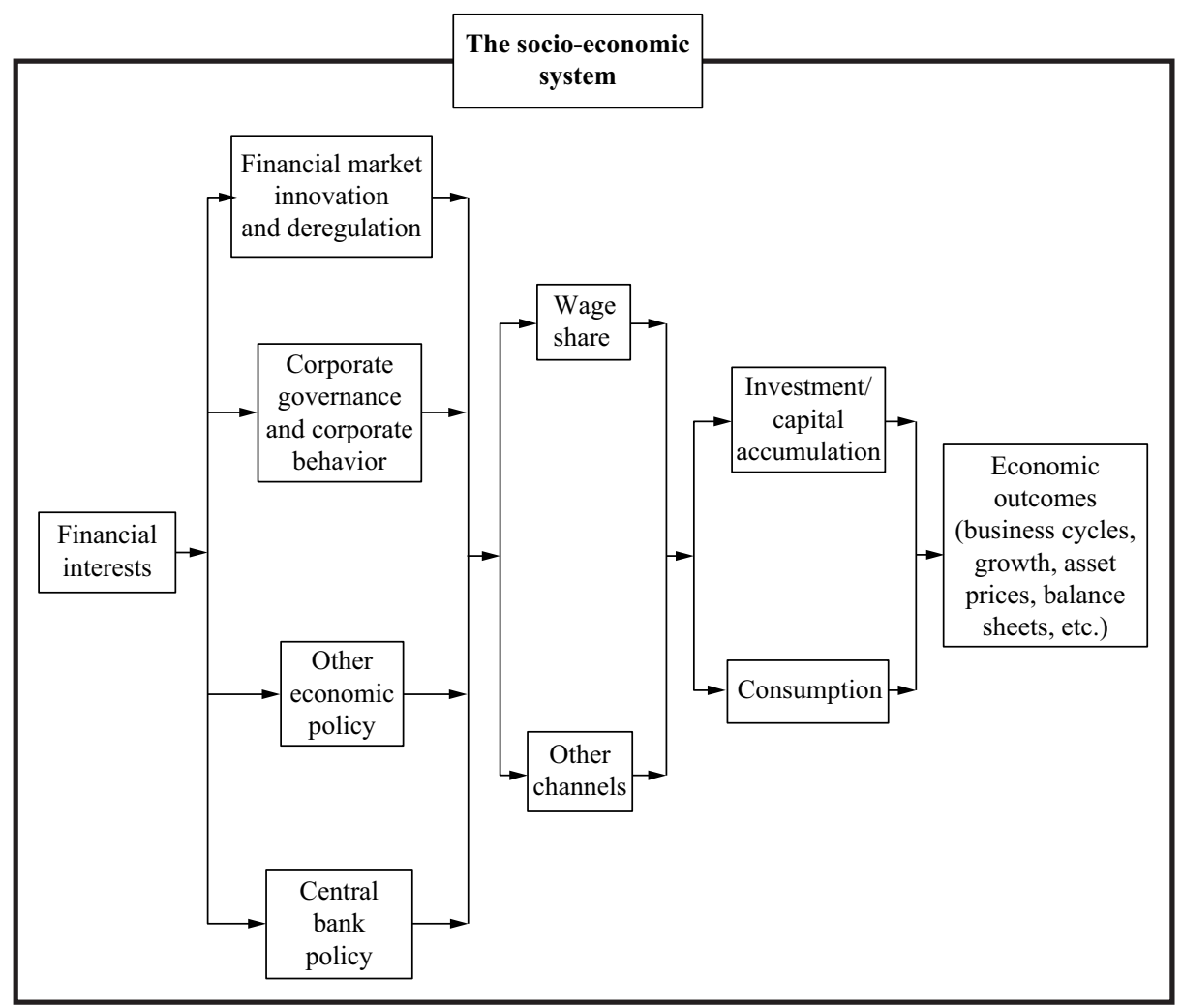

Figure 2 A simple diagrammatic model of financialization

policy. As discussed later, central banks are a lynchpin of financialization, which means they and their policies deserve stand-alone attention. ${ }^{4}$

Figure 2 specifically identifies the wage share as a stand-alone transmission mechanism. The wage share is a critical component of the Neo-Kaleckian approach to growth, and it is also a critical variable for explaining income inequality. Neoliberalism reduces the wage share. Financialization also does so, both by amplifying Neoliberal policies and by its own additional impacts. The 'other channels' box refers to multiple channels such as wealth effects from higher asset prices, asset price effects on investment, and increased supply of credit (business and consumer) effects. Many of those channels are noted in Hein and van Treeck (2010). Continuing through the

4. Recognizing the special place of central banks within the financialization process provides another frame for understanding controversies like central bank independence, with the latter becoming a way of enhancing the power of finance. Rather than being an institutional design to improve monetary policy, independence is a design that enhances the power of finance over monetary policy (Palley 2019). There is a long history of central banks being identified with financial interests. In the United Kingdom in the 1920s and 1930s, that interest was reflected in the policies of the Bank of England. The bank was headed by Montagu Norman who was an advocate of a disastrous gold standard policy that was supported by London's financial interests. 
diagram, the effects flow through to impact capital accumulation and consumption, which in turn impact macroeconomic outcomes (economic activity, business cycles, and growth) and balance sheet positions (debt ratios, etc.).

\subsection{Macro stylized facts}

The second column in Figure 1 refers to the stylized facts and characterization of financialization which empirically define the phenomenon. Krippner (2005) provides an early empirical characterization. Other summaries are provided by Palley (2007) and Lapavitsas (2009), and the picture has been updated by Hudson (2021). Booklength treatments of financialization are provided by Orhangazi (2008a), Hein (2012), and Palley (2013).

The original impulse for theorizing financialization was developments in the US economy, but it was soon shown to be a global phenomenon as documented by Epstein and Jayadev (2005). There are three stand-out empirical macroeconomic features in the US data. The first is the large increase in the Finance, Insurance, and Real Estate (FIRE) sector share of GDP. The second is the change in the income composition of GDP. That composition is illustrated in Figure 3, which shows a tree diagram describing the functional distribution of income. Financialization has been associated with an increase in the capital share at the expense of the labor share. Within the capital share, interest payments have increased at the expense of profits. Additionally, the financial sector share of profits has increased at the expense of the non-financial sector's share of profits. Within the wage share, the share paid to the managerial and professional class has increased at the expense of the share paid to non-managerial workers. The latter constitute about 80 percent of employment in the US economy. This wage share redistribution is reflected in the increased inequality of personal income distribution.

The third is the increase in the debt-GDP ratio, which is accompanied by an increase in the debt-GDP ratio across all sectors of the economy (household, non-corporate financial, financial, and government). This change in the debt-GDP ratio reflects the balance sheet effects of financialization. The mechanics behind those balance sheet effects are a principal focus of the current paper.

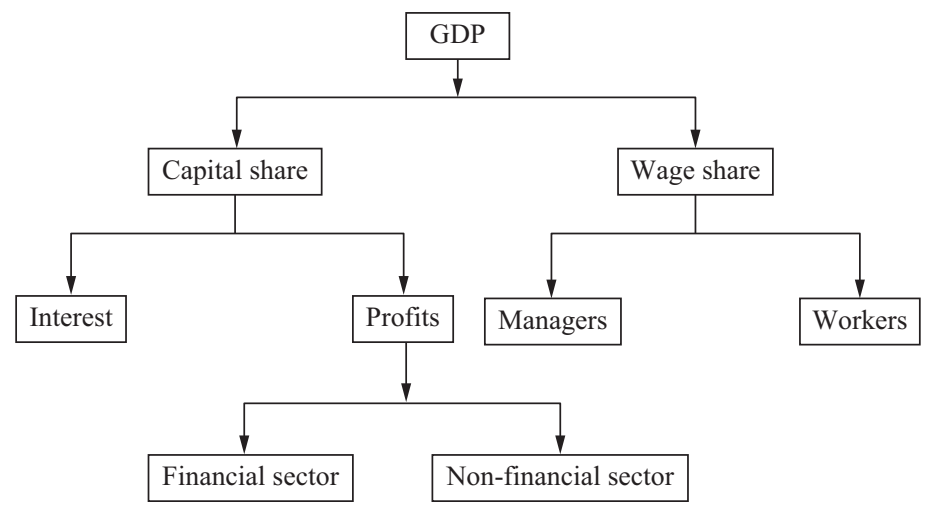

Source: Palley (2007 [2008], p. 12).

Figure 3 Financialization and the functional distribution of income 
Lastly, mainstream economists have also picked up on the growth of finance (Greenwood and Scharfstein 2013). However, they have no equivalent of the financialization hypothesis. ${ }^{5}$ That absence likely reflects its fundamental difficulty with viewing the economy as a political socioeconomic system.

\subsection{Financial market innovation and deregulation}

The third column of Figure 1 concerns financial market innovation and deregulation, which is one of the obvious sources of financialization. Both financial innovation and financial deregulation have attracted significant attention as explanations of the global financial crisis of 2008. Palley (2012, ch. 5, 'The role of finance') documents the scale and significance of financial innovation and deregulation in supercharging the US financial system and promoting the highly leveraged fragile financial structures that eventually brought the system to its knees in 2008. Regulatory failure can also be viewed as part of financialization, with finance pressuring regulators to go light and overlook failings. In that regard, Jarsulic (2010) documents the extensive failure of US financial regulation and how it contributed to the 2008 crisis.

\subsection{Corporate governance and corporate behavior}

The fourth column of Figure 1 concerns corporate governance and corporate behavior. Financialization changes financial markets, but it also needs to gain traction within the real economy. Corporate governance and corporate behavior is a key mechanism whereby it does so. That mechanism ties financialization to the shareholder value maximization (SVM) paradigm which claims it is privately and socially optimal for corporations to maximize profits (Friedman 1970). Operationalizing such behavior in managerially controlled firms calls for incentive contracts (for example, stock options) that are supposed to align shareholders' and managers' interests, plus a market for corporate control (that is, the stock market) which allows shareholders to discipline poorly performing managers (Jensen and Meckling 1976).

That framework gives Wall Street righteous control over firms, and financialization has rendered it dominant. However, the SVM paradigm has been severely criticized (Lazonick and O'Sullivan 2000; Lazonick 2014) for promoting corporate strategies that overdistribute profits, overleverage firms with debt as part of inefficient stock buy-backs which pump the value of managers' stock options, and reduce expenditures on capital accumulation and $\mathrm{R} \& \mathrm{D}$ which are necessary for the long-term growth of the firm.

SVM theory provided the ideology and justification for adoption of the SVM corporate governance paradigm. However, policy was absolutely critical. Stock buybacks are a centerpiece of the SVM model in practice, but prior to the financialization era such buy-backs were prohibited. That changed with the 1982 Securities and Exchange Commission ruling (SEC Rule 10B-18) which permitted buy-backs. Absent that ruling, the SVM model would have been significantly stunted. The ruling provides an explicit example of the importance of policy, but the fingerprints of policy can be found on almost every dimension of financialization.

5. Kohler et al. (2019, fn 7$)$ also note that mainstream economists have shied away from the construct of financialization. 


\subsection{Central banks and financial regulatory agencies}

The fifth column of Figure 1 concerns central banks and financial regulatory agencies. Those institutions are responsible for regulatory oversight and for many policies that affect financial markets. As discussed above, deregulation and light-touch regulation have promoted the expansion of the US financial sector. Central banks are the single most important of these agencies and they have been critical in three ways: in their capacity as financial regulators, in their monetary policy capacity whereby they set interest rates, and in their capacity as 'lenders of last resort' which ensure market liquidity and oversee bail-outs to troubled financial institutions. The role of central banks has been fundamental to financialization, both in shaping it and sustaining it. That fundamental role is examined in Sections 5-7 below.

\subsection{Income distribution}

The sixth column of Figure 1 refers to income distribution, and it maps into the wage share box in Figure 2. Neoliberalism has reduced the wage share through multiple channels that include increased labor market flexibility (that is, diminished union power, diminished employee protections, a lower minimum wage, etc.), globalization, and increased economic insecurity. The theoretical justification for an independent effect of financialization also involves multiple channels. Those include an increased mark-up arising out of corporate behavior (Hein and van Treeck 2010), increased corporate indebtedness that pre-commits income to interest payments and squeezes workers with the threat of bankruptcy (Bronars and Deere 1991), and increased household debt that lowers worker bargaining power by rendering them financially vulnerable (Kim et al. 2019). Hein (2015) presents a comprehensive discussion of the effect of financialization on the wage share from a Kaleckian perspective. Dünhaupt (2016) provides empirical evidence of a dividend payment financialization effect on the wage share in OECD economies.

Kohler et al. (2019) summarize the existing literature (see references therein) and provide further multivariate regression evidence supporting the claim that financialization negatively impacts the wage share. After controlling for the impact of Neoliberalism, they report a statistically significant negative impact of their two financialization variables which proxy for domestic and international financialization respectively. From a systems perspective the effect may be even greater because financialization amplifies Neoliberalism. Consequently, some of the former's impact may flow through the Neoliberal control variables. That illustrates the analytical importance of understanding the relationship between financialization and Neoliberalism, which was discussed earlier.

\subsection{Capital accumulation}

The seventh column in Figure 1 concerns financialization's impact on capital accumulation, which is closely connected to its impact on growth as accumulation is a critical determinant of growth. The impact on capital accumulation raises the recurrent difficulty of distinguishing between the effects of Neoliberalism and financialization. Additionally, it raises difficulties regarding the theoretical determinants of investment, and difficulties distinguishing between short-run and long-run impacts.

If critics of the SVM model are right, financialization lowers accumulation via changed managerial behavior. A lower wage share may also lower investment if it 
reduces economic activity (that is, capacity utilization) and investment is impacted by economic activity. Balanced against that, an increased profit share may raise investment via a profit rate and an asset price effect. The net effect is therefore theoretically ambiguous. That said, the empirical consensus is that financialization has a negative impact (Stockhammer 2004; Orhangazi 2008b; Tori and Onaran 2017).

\subsection{Consumption}

The eighth column in Figure 1 concerns financialization's impact on consumption. Here, financialization has offsetting effects, which are further complicated by potential differences in short-run and long-run impacts. The lower wage share will tend to depress consumption if lower income households have a higher marginal propensity to consume. That outcome rests on Duesenberry's (1949) relative income theory of consumption which explains such differential behavior (Palley 2010b). Balanced against that, consumption will tend to be increased by higher asset prices resulting from an increased profit share. Financialization will also increase consumption to the extent that it reduces liquidity constraints by increasing access to and availability of credit.

That raises the issue of consumer debt which may temporarily mask negative effects. Thus, the negative consumption impact of a lower wage share may be temporarily offset by increased debt-financed consumption, but that positive effect may reverse later owing to debt burden effects. Again, consumption theory is important since such masking requires either habit-based behavior or 'Keeping up with the Joneses' behavior (Frank 1985; Cynamon and Fazzari 2008; Barba and Pivetti 2009; Frank et al. 2014). The empirical consensus is that financialization increased household indebtedness and debt-financed consumption. The accumulated debt then deepened the global financial crisis of 2008 and the stagnation that ensued (Cynamon and Fazzari 2016).

\subsection{Business cycles and financial crises}

The ninth column in Figure 1 concerns financialization's impact on the business cycle and its proclivity to generate financial crises. The Post-Keynesian literature on financialization has tended to focus on growth (see below) and a proclivity to near-term stagnation (Cynamon and Fazzari 2008; 2016; Barba and Pivetti 2009; Palley 2012, ch. 8, 'The coming great stagnation'; Stockhammer 2015). An alternative focus is the business cycle, and Palley (2005) argues financialization has created a new business cycle driven by household borrowing and asset price inflation. The theoretical framework for such a cycle is developed in Palley (1994; 1997a).

Descriptively, the new business cycle is characterized by much longer upswings, combined with much sharper downturns that are triggered by bursting of asset price bubbles and by accumulated debt burdens that undermine AD. Moreover, the cycle is prone to instability, which calls for policy interventions that put a floor in place and reset the economy.

A business cycle perspective redirects attention to policy. In particular, central banks are a critical part of the financialization landscape. Not only have they been involved in the deregulation of finance which has structurally facilitated financialization, they are critical to the financialization cycle. When the economy crashes, central banks are called upon to put a floor under financial markets. Thereafter, when the economy gets trapped in stagnation, central banks are called upon to reflate asset 
prices and jump-start a new cycle of lending. This role of central banks is largely absent in the theoretical literature, and is examined in Sections 5 and 6 below.

\subsection{Growth}

The tenth column in Figure 1 concerns financialization's impact on long-run growth. This literature concerns steady-state growth, which may be a figment if financialization is unstable or unsustainable. The effects of financialization also depend on the particular growth theory adopted. Furthermore, even within a particular perspective the outcome depends on the characteristics of the economy.

In the Neo-Kaleckian perspective, which tends to dominate among Post-Keynesians (see for example Hein and van Treeck 2010), the impact on growth is strongly dependent on whether the economy is 'wage-led' or 'profit-led.' In wage-led economies the growth impact is negative, whereas in profit-led economies it may be positive. That is because a higher profit share increases the accumulation rate, and that effect may dominate other negative effects of financialization on accumulation. In classical growth models with supply constraints, the outcome depends on the relative impact on the saving and investment rates. Ryoo and Skott (2008) show that in such economies financialization is likely to be positive for plausible parameters. An interesting insight from growth models is that a higher debt ratio can be associated with faster growth as the positive demand effect of new borrowing can dominate the negative debt service effect. The critical condition is that the growth rate exceeds the interest rate (Dutt 2006; Palley 2010c).

These observations are intended to show that it is difficult to draw conclusions about the growth effect of financialization. Instead, it may be more productive to view financialization in terms of its impact on distribution, financial stability, the business cycle, economic policy, and political economy.

\subsection{International finance}

Lastly, financialization has also had an enormous influence on international finance. This is an area in which the amplification of Neoliberalism is clear. Until the 2008 global financial crisis, the Neoliberal era witnessed rapid trade growth, which was combined with globalization that remade the global structure of production (Palley 2018). The increase in trade has required increased trade finance, while globalization has driven increased foreign direct investment. International financialization has prompted the removal of financial capital controls, and the resulting international financial openness has made for greater movement of portfolio (that is, financial) capital. As documented in Pérez Caldentey and Vernengo (2021), there have also been other major changes in the composition of financial flows to emerging market economies and those compositional changes have tended to further amplify procyclicality.

Both Jayadev (2007) and Stockhammer (2017) report increased international financial openness is associated with a lower wage share. There is also evidence that increased international financial openness has increased country proclivity to financial crisis. Two decades ago Glick and Hutchinson (1999) documented that 'twin crises' (that is, simultaneous banking and currency crises) became more frequent in the 1980s and 1990s. Recently, the IMF (Laeven and Valencia 2018) has documented that the sharp global increase in systemic banking crises extended into the 2000s. 


\section{THE MECHANICS OF THE VAMPIRE SQUID ECONOMY: BALANCE SHEET LOADING}

The above analysis shows the multiple dimensions of financialization, which reach deep into the economy and touch every major sector. Mathematical models tend to focus on equilibrium, but that may miss the main story in financialization which is about the evolving process and policy. Process is important because financialization evolves organically. Policy is important because it is critical in promoting and sustaining financialization, and with policy comes political economy.

The balance of the paper focuses on these three features: process, policy, and political economy. Public interest in financialization is driven by the problematic process and the policy interventions it compels. There are two aspects to this interactive dynamic between process and policy. First, profit-seeking by non-financial and financial corporations has them using and providing debt finance as a means for increasing profit. Second, that process generates outcomes which compel policymakers to intervene to sustain $\mathrm{AD}$ and avoid a collapse in economic activity. Together, that creates a treacherous feedback loop. The 'borrowing' and asset price inflation associated with provision and use of debt finance initially strengthens $\mathrm{AD}$, but ultimately weakens AD via the resulting debt burdens and income distribution effects. That compels fresh policy interventions to jump-start the process anew. This pattern has repeated in the four full US business cycles of the financialization era (1981-1990, 19912000, 2001-2008, 2009-2020). It has also been evident in the jump-starting of the business cycle following the 2020 COVID-19 pandemic which brought the last expansion to a premature end.

The vampire squid character of financialization is evident in the way the process embraces every sector of the economy. That includes the government sector, which has been underappreciated in discussions of financialization.

\subsection{Financialization and the household sector: consumer credit}

Figure 4 shows financialization's embrace of the household sector via provision of consumer credit. Metaphorically speaking, the FIRE sector is the vampire squid. Its role is to initially provide credit to households (who become debtor households) and then funnel the debt service payments and fees to the owner (capitalist) households. This is the core structure of the consumer credit business cycle model presented in Palley $(1994 ; 1997 a)$. Borrowing is initially expansionary as debtor households spend those borrowings. However, the resulting debt burdens are contractionary. The necessary assumption for that contractionary effect is that debtor households have a higher marginal propensity to consume than owner households. In that case the transfer of income from debtor households to owner households lowers AD.

\subsection{Financialization and the household sector: residential real estate}

Figure 5 shows financialization's embrace of the household sector via residential real estate. Once again, the FIRE sector serves to channel payments from ordinary (debtor) households to owner households. It does this via the dividend and interest distributions FIRE pays to its owners. However, the residential real estate margin of engagement is more complicated as there is a house-buyer-house-seller transaction. FIRE provides the purchase finance to the new buyer, who must then service the mortgage. The seller 


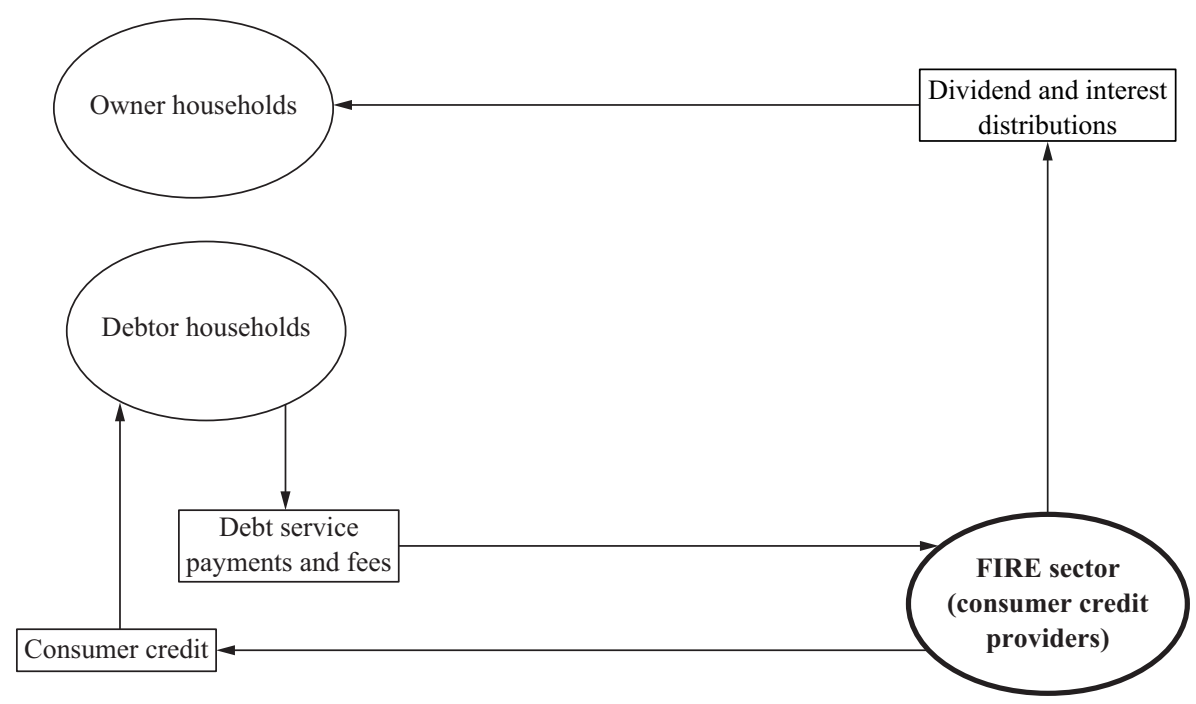

Figure 4 Financialization and the household sector (consumer credit)

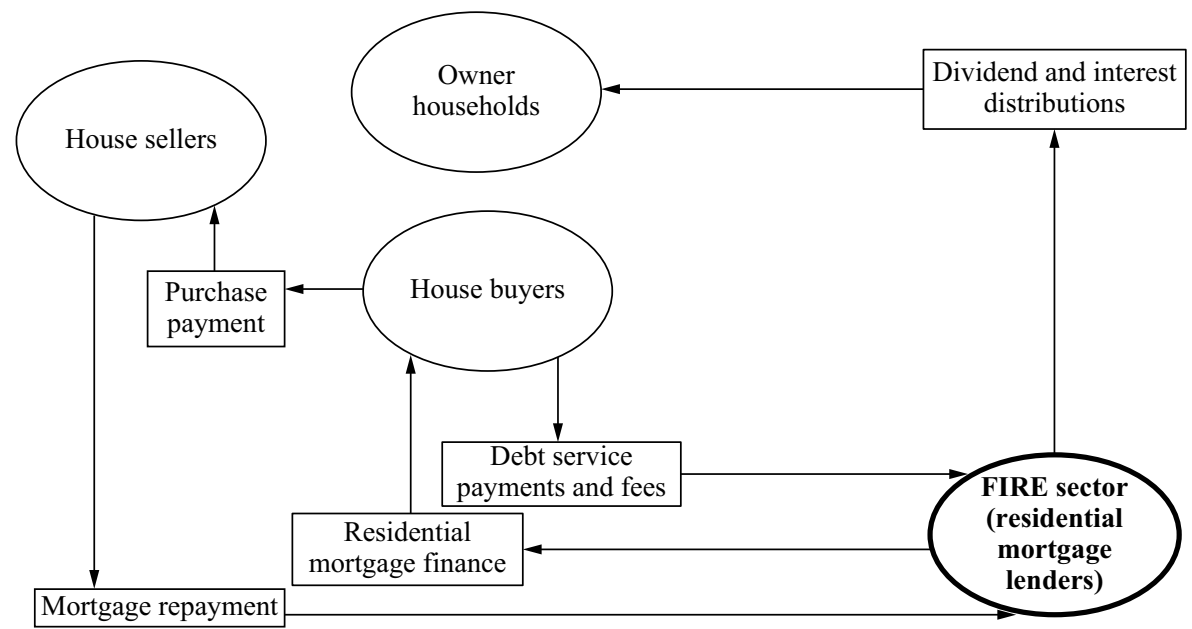

Figure 5 Financialization and the household sector (residential real estate)

repays the outstanding balance on their mortgage and retains the home equity (that is, the difference between sale price and outstanding mortgage balance). ${ }^{6}$

There are multiple features to note about the financialization of residential real estate. First, FIRE provides residential mortgage finance and is instrumental in raising house prices. By making mortgage credit more widely available, it enables the

6. For newly constructed homes, the seller is the construction company. It uses the sale proceeds to repay loans taken to finance the new construction, renew working capital, and make dividend and interest payments. 
bidding up of house prices. Second, FIRE is a winner from higher house prices as higher prices mean larger mortgages and larger interest payments, ceteris paribus. Third, lower interest rates will increase house prices by making a larger mortgage balance affordable. However, FIRE's income is protected from declines in the mortgage interest rate by the resulting increase in mortgage values. Fourth, FIRE has also been protected from trend decline in interest rates by repeated refinancing waves of existing mortgages, as refinancing involves large fee payments.

Fifth, new buyers take on highly leveraged positions that render household balance sheets fragile. The value of the home as a financial investment is contingent on what it can subsequently be sold for. Therein lies the danger of a bubble that can destroy the household sector's balance sheet. Thus, if the household sector engages in an extended period of home buying at elevated prices, and the factors driving high prices prove temporary or go into reverse, house prices will subsequently fall. Having been winners from rising house prices, existing homeowner sellers lose from falling prices and can be bankrupted. Sixth, halving the interest rate and doubling the mortgage amount is non-neutral. Though the total interest payment is the same, the household balance sheet is more leveraged and the household must pay back a larger mortgage over the life of the mortgage. Lower interest rates therefore inject unnoticed financial stress into the household sector via this channel.

Seventh, financialization of residential real estate has major political implications. Houses are increasingly viewed as investment vehicles and an important part of retirement income plans. That, combined with the fact homeowners are significant debtors, lends political support to asset price support policy that benefits financial interests. Another implication is the aggravation of conflictual generational (young vs old) politics. Existing homeowners tend to be older so that they benefit from rising house prices at the expense of younger buyers. Financialization of residential real estate therefore politically fractures the worker household sector by introducing a division between young and old households.

\subsection{Financialization and the household sector: retirement saving}

Figure 6 shows the financialization of household retirement saving, which has centered on a move away from employer-provided defined benefit arrangements to a

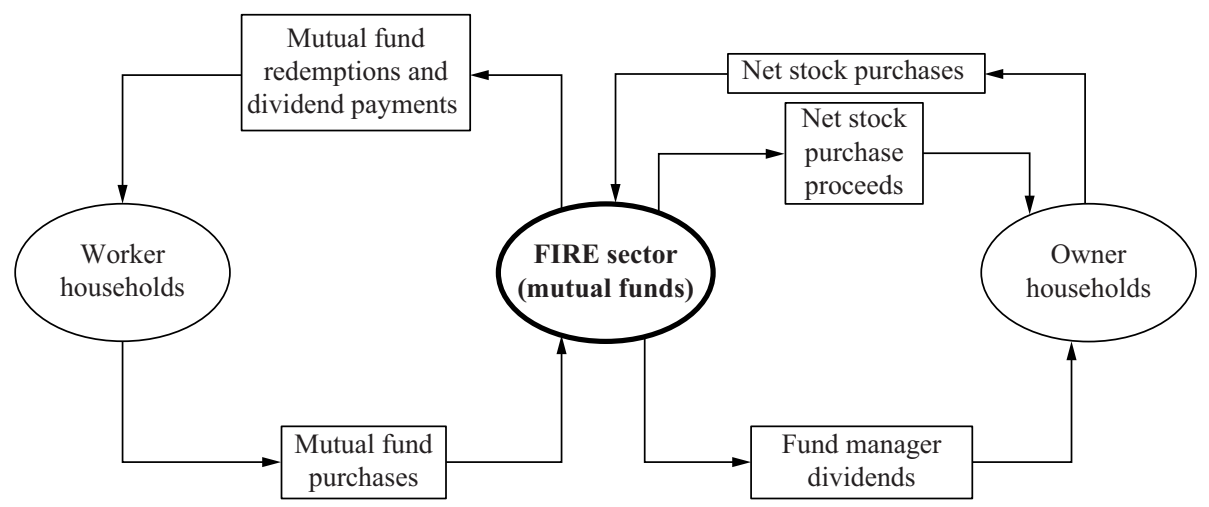

Figure 6 Financialization and the household sector (retirement saving) 
system based on personal saving and employer-defined contribution arrangements. That shift is a major factor behind the explosion in size of the asset management sub-sector of FIRE. In the new system, instead of receiving a fixed pension from employers, workers invest their own retirement savings. Those savings are channeled into financial markets through mutual funds, which buy financial assets from existing asset owners. ${ }^{7}$ The FIRE sector manages those funds and charges fees in return, which it then pays to the owners of the mutual fund sponsor.

Once again, there are multiple features to note. First, the transition to the new system, combined with favorable 'baby boom' demographics, has meant worker households have increased their mutual fund holdings over the past 40 years. That has increased the demand for equities and driven up equity prices, which explains finance capital's support for the system. Not only do finance capital interests get to levy fund management fees, they also benefit from higher equity prices. However, sales of mutual funds by retirees can reverse the direction of that flow, putting downward pressure on equity prices. That explains finance capital's persistent political pressure to remove mandatory annual retirement distributions.

Second, households now bear increased uncertainty regarding retirement income which depends on their investment decisions and asset market performance. Third, as noted earlier, financialization of retirement income creates a new political economy whereby worker households' interests are tied to asset markets. That may affect their political alignment by inducing them to identify with financial capital. Fourth, FIRE benefits from higher asset prices as fund fees are calculated on the basis of the value of assets under management. Fifth, owners of assets (including corporations that issue new equity) have an interest in higher asset prices as they have been net sellers to mutual funds. That means there is a political economic alliance spanning owners of capital and the FIRE sector, plus worker households to a lesser degree. All have an interest in having policy inflate asset prices and then stepping in to support those inflated valuations. Fifth, as with residential real estate, there is a danger of a bubble which leaves worker households exposed to losses and diminished retirement income. However, the macroeconomic damage from a financial market price bubble is far less than that from a residential real estate price bubble as the latter is based on leverage (that is, mortgage finance) and can destroy the household sector's balance sheet.

In sum, Figures 4, 5, and 6 show how financialization has deeply permeated the household sector through three critical margins: consumer credit, residential real estate, and retirement income provision. The monetary amounts involved are enormous, which explains the lucrative returns and increased size of the FIRE sector. Individual households are increasingly like leveraged mini-hedge funds, holding variable price assets (mutual funds and housing) plus fixed price consumer and mortgage debt. The financialization of the household sector also likely has political impacts by encouraging worker households to think they have an identity of interest with financial interests.

\subsection{Financialization and the non-financial corporate sector}

Figure 7 shows financialization's embrace of the non-financial corporate sector. It reflects application of the SVM hypothesis advocated by Friedman (1970) and Jensen

7. Corporations are also issuers of financial assets (bonds and equities) which mutual funds may buy. 


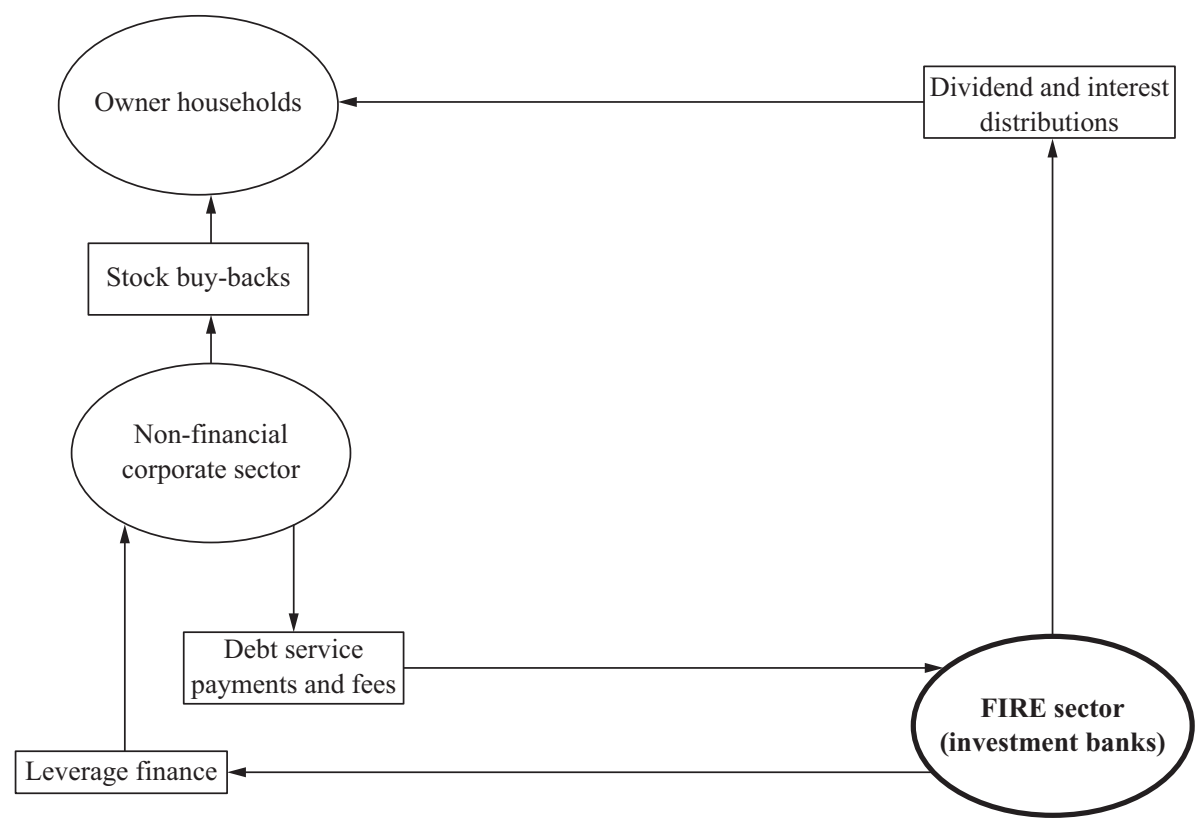

\section{Figure 7 Financialization and the non-financial corporate sector}

and Meckling (1976). Accordingly, firms have engaged in stock buy-backs funded by debt provided by the FIRE sector. Debt is preferentially treated by the tax code relative to equity, which lowers firms' cost of capital. Additionally, debt leaves less discretionary income within the firm, thereby putting the squeeze on labor's share (Bronars and Deere 1991). The individual firm's owner benefits directly as stock buy-backs bid up the equity price of individual firms. The FIRE sector benefits from the interest and fees associated with financing stock buy-backs, which are passed on as dividends and interest to FIRE sector equity and bond holders. The principal macroeconomic downsides discussed earlier are a reduced wage share which may slow growth in a wage-led economy, and a lower rate of capital accumulation by firms owing to financing constraints resulting from increased balance sheet leverage.

\subsection{Financialization and the government sector}

Financialization has also embraced the finances of the government sector. ${ }^{8}$ That impact of financialization on government finances has been little commented on as it has been viewed through the lens of austerity and Keynesian stabilization policy. Introducing financialization into the picture improves understanding of fiscal policy developments since 1980 .

The era of Neoliberalism (1980-today) has been associated with fiscal austerity, yet it has also been an era of large budget deficits, particularly in the US. Financialization is

8. As discussed earlier, financialization has also impacted the economy through privatization of government services. However, having been purchased, privatized firms pass into private ownership and are influenced by financialization in that role. 


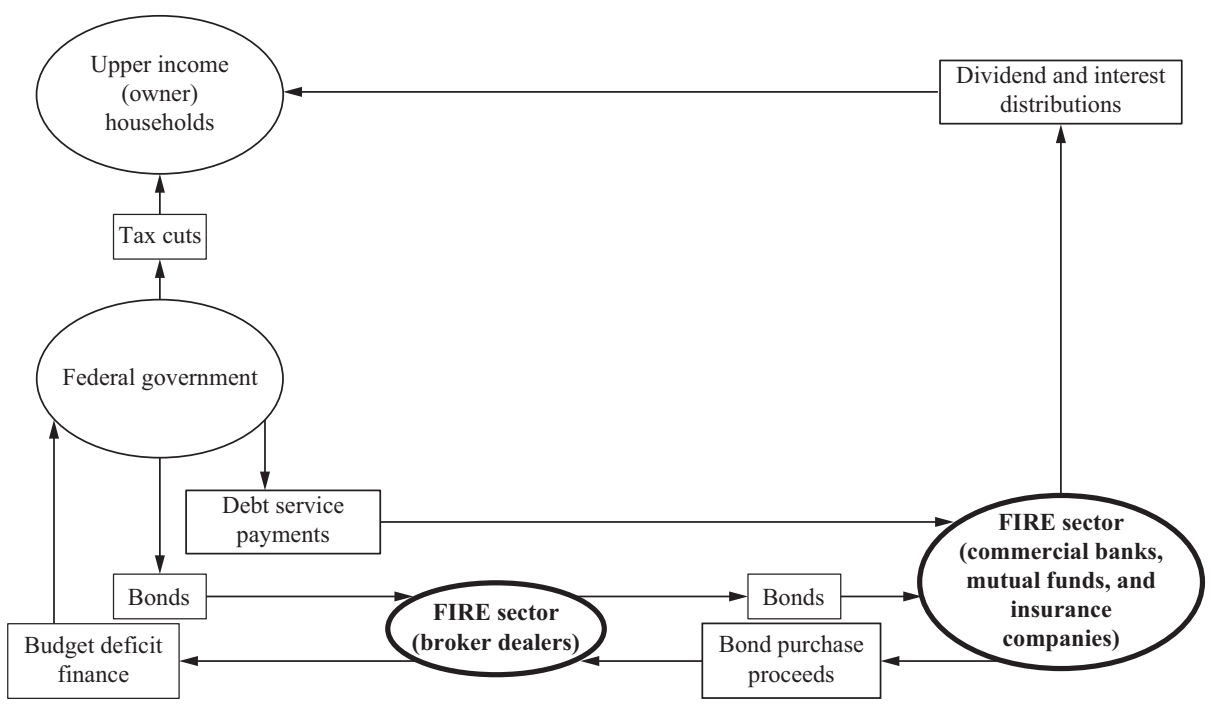

Figure 8 Financialization and the federal government sector

the key to unraveling that apparent contradiction as financial interests like large budget deficits, especially when real interest rates are high as they were in the 1980s. Neoliberal policy has cut tax rates on both corporations and upper income (owner) households, and those tax cuts generated large budget deficits which required financing. In the US, there have been three major rounds of tax cuts: the Reagan tax cuts in the early 1980s, the Bush-Cheney tax cuts in the early 2000s, and the Trump tax cuts in 2017.

As illustrated in Figure 8, the FIRE sector has financed those tax cuts. The financing process involves two steps. Step 1 has government selling its bonds to bond market broker dealers. Step 2 has the dealers then selling the bonds on to commercial banks, mutual funds, and insurance companies who are the long-term holders. Those financial firms then receive the bond interest which is passed on as dividends and interest payments to their financial backers. The FIRE sector therefore benefits twice, as bond dealer and as bond holder.

In many ways, the pattern in Figure 8 is the public sector analog of the pattern in Figure 7 which shows how non-financial corporations have leveraged their balance sheets. In a sense, Neoliberal financialization has had government doing the same. Thus, tax cuts have effectively returned income to upper-income households. At the same time, they have loaded the government balance sheet with debt, which is disproportionately held by upper-income households. Consequently, as with corporate leverage, the interest payments disproportionately go to them.

Finally, interest payments on the debt effectively pre-commit future tax revenues which cannot be used for discretionary government spending. If there is resistance to raising taxes, either for political reasons or for microeconomic efficiency reasons, that pre-commitment of revenues tends to squeeze discretionary social spending. ${ }^{9}$ That squeeze is akin to how corporate leverage squeezes the wage share by pre-committing corporate cash flows.

9. Discretionary military spending tends to be exempted. 


\subsection{Micro and meso economic forces}

The above analysis shows the pattern of transactions driving the financialization process in different sectors. That process is supported by powerful micro and meso economic forces.

In the corporate sector, the notion of SVM (Friedman 1970; Jensen and Meckling 1976) is now the ideology of the managerial class and is taught in business schools and economics departments. That has created a powerful microeconomic force whereby managerial pay arrangements are designed to combat agency problems (Ross 1973), so that managers are given stock option awards to induce them to identify with shareholders and therefore act in shareholders' interests. Those incentive pay arrangements may then interact with and amplify other mechanisms of managerial failure - such as inappropriate setting of managerial awards owing to failures of internal corporate governance (Bebchuk and Fried 2004) and managerial short-termism (Palley 1997b).

Their impacts may also be amplified by Minsky's 'financial instability hypothesis' (Minsky 1992b [1993]; Palley 2011) whereby managers and capital market participants become increasingly over-optimistic over the course of the business cycle, leading them to take on greater leverage and balance sheet risk. However, to be clear, the Minsky mechanism operates in all economies. Financialized economies just give it greater and easier play.

In the household sector, the proclivity to increased debt has been driven by the lowered wage share that has driven households to seek to maintain their standard of living via debt (Cynamon and Fazzari 2008; Barba and Pivetti 2009). That response is underpinned by both habit and 'keeping up with the Joneses' consumption behavior that is rooted in humans' rivalry and quest for status (Duesenberry 1949; Frank 1985; Palley 2010b; Frank et al. 2014). Financialization amplifies the impact of those rivalrous tendencies by expanding the supply of credit.

Credit supply expansion can have especially negative impacts via real estate markets which are characterized by relatively inelastic supply. Consequently, households get caught in a zero-sum competition whereby they bid up the price of homes against each other, resulting in increased household mortgage debt.

\section{THE ROLLING DYNAMICS OF THE VAMPIRE SQUID ECONOMY}

The previous section showed how the vampire squid economy has embraced every sector of the economy. This section examines the rolling dynamics of financialization whereby it rolls from sector to sector, leveraging sector balance sheets. The section draws on Palley (2009), who describes financialization as developing in stages, moving from one sector to the next.

The vampire squid process involves a leveraging process that rolls from sector to sector. Debt is the key instrument of the vampire squid economy whereby income is redistributed to upper income groups, and it is also central to the asset inflation process. At the macroeconomic level it is a two-edged sword. New borrowing tends to increase current $\mathrm{AD}$, but the resulting debt burdens tend to reduce future $\mathrm{AD}$.

Government debt is critical in this process. As the private sector's balance sheet becomes congested, the process reverts to the public sector balance sheet to provide fresh impetus. Moreover, since 2008, the process has embraced the Federal Reserve's balance sheet, with the central bank being called upon to buy private debt to sustain its market value and create room for more issue. 
Figure 9 represents the rolling process through the four business cycles that have marked the US economy during the era of financialization. The federal government deficit and accompanying increased debt were key to launching the long expansion of the 1980s, which was then taken up and carried forward by household and business debt. When the expansion ended in 1991, the federal government sector stepped in again. After a prolonged jobless recovery, the expansion took off, again fueled by household and business debt growth. When that expansion tripped in 2001, the federal government sector jump-started another recovery. That recovery was substantially carried forward by household mortgage debt which drove a house price bubble. When the bubble burst, it provoked the 2008 global financial crisis. Once again, the government sector was forced to step in and its balance sheet was put into service to jump-start the economy with federal budget deficits. However, this time, the Federal Reserve's balance sheet was also enlisted as it purchased private sector debts to sustain their value (so called quantitative easing or QE), and it also bought large quantities of federal debt. That development represents a significant extension in the vampire squid process of balance sheet loading.

Figure 9 contains two dividing lines. The dashed line marks the recession of 2001 which, though relatively shallow, marks a divide. First, the recovery was slow and tenuous despite the recession being shallow, and despite enlisting the federal government's balance sheet to finance large deficits. Second, the budget deficit was effectively ratcheted up so that the government-debt-GDP ratio started rising, and that is now a permanent feature of the economic landscape. The solid line marks the global financial crisis of 2008. That generated a further ratcheting up of the budget deficit, and also put the Federal Reserve's balance sheet in the service of the vampire squid economy. At this stage, large-scale access to both the federal government's balance sheet and the Federal Reserve's balance sheet are necessary to keep the vampire squid economy from imploding.

Table 1 shows sector-debt-GDP ratios for selected years and provides evidence supportive of the narrative in Figure 9. The selected data points correspond to business cycle peak years, and the years from 1980 onward provide a picture of peak-to-peak developments. The end year is 2019, which avoids the distortions caused by the COVID-19 pandemic.

There are multiple features to note. First, the table shows that 1980 marks a break. Prior to 1980 , the domestic non-financial debt-GDP ratio was stable. Within that, the federal government ratio was falling, while the private sector (household and business) ratio was rising slowly. After 1980, all that changes. The aggregate non-financial ratio, federal government ratio, household sector ratio, and business sector ratio all start rising rapidly.

Second, the federal government balance sheet starts to play a critical role in driving the economy. Federal debt rises rapidly in the 1980s (owing to tax cuts and increased military spending) as part of driving the expansion, but the expansion is also supported by economic activity driven by private sector debt. In the 1990s, the federal government's role is diminished as the financialized economy bulks up on private sector debt-led growth. However, from 2001 onward the federal government's balance sheet is increasingly enlisted to drive the economy, as reflected by the accelerating increase in the federal debt ratio.

The business sector's debt-GDP ratio has risen steadily. Within that, the corporate sector's ratio rose more rapidly between 1980 and 2001, reflecting the leveraged buyout boom and the arrival of the stock buy-back movement. It has also risen slightly more rapidly since 2008 .

The household debt ratio rose rapidly through to 2007 , driven significantly by mortgage debt growth. It fell back sharply after the 2008 global financial crisis which caused significant mortgage default that wiped out debt. Thereafter, there followed a multi-year real estate recession in which new mortgage issuance fell, but existing 
480 Review of Keynesian Economics, Vol. 9 No. 4

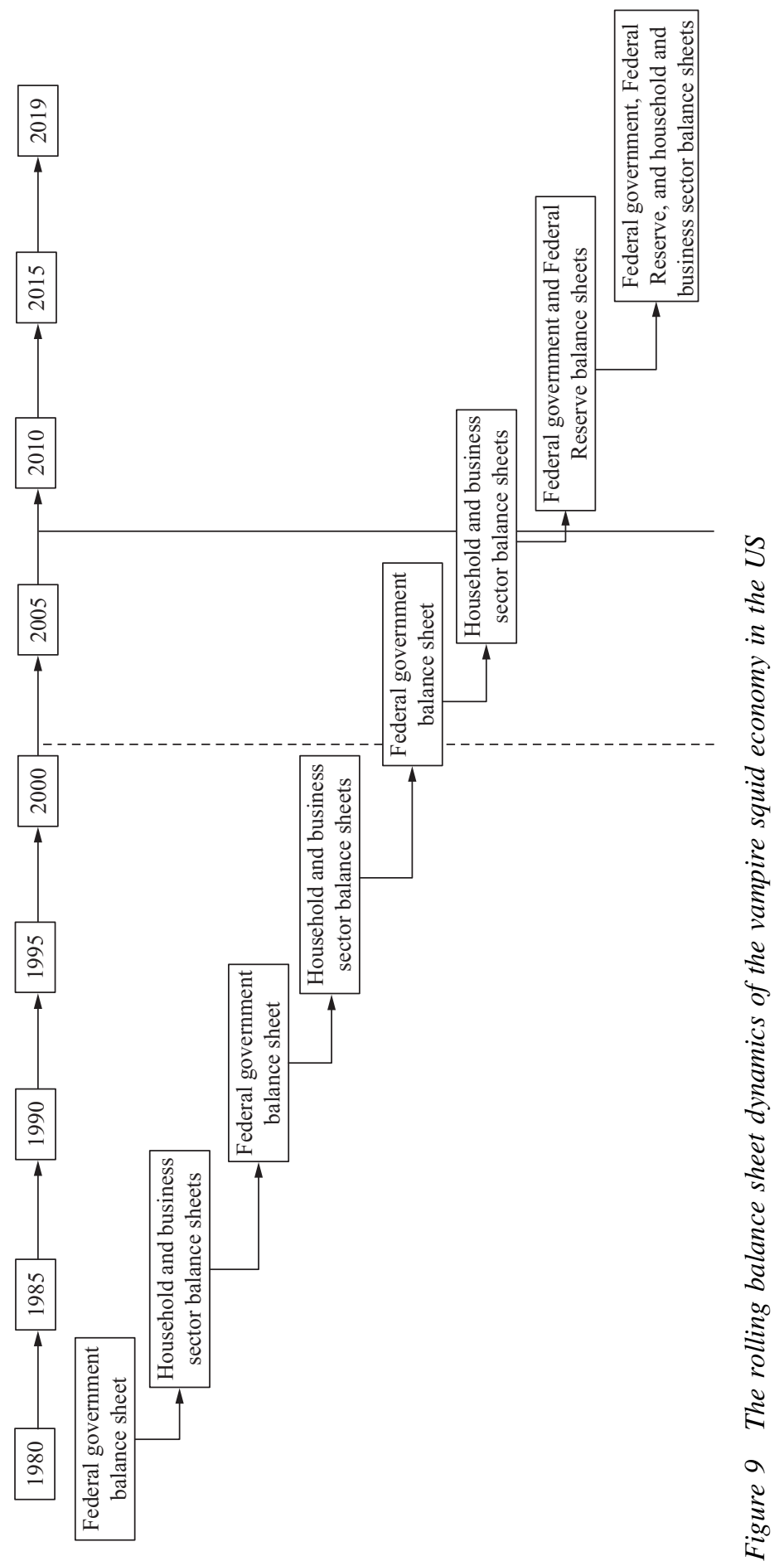




\section{Table 1 Sector debt-to-GDP ratios}

\begin{tabular}{cccccccc}
\hline & $\begin{array}{c}\text { Domestic } \\
\text { non-financial } \\
\text { sector }\end{array}$ & $\begin{array}{c}\text { Federal } \\
\text { government }\end{array}$ & Household & $\begin{array}{c}\text { Household } \\
\text { mortgage }\end{array}$ & $\begin{array}{c}\text { Household } \\
\text { consumer } \\
\text { credit }\end{array}$ & Business & $\begin{array}{c}\text { Business } \\
\text { corporate }\end{array}$ \\
\hline 1960 & 1.39 & 0.47 & 0.41 & 0.26 & 0.11 & 0.38 & 0.27 \\
1969 & 1.39 & 0.32 & 0.46 & 0.28 & 0.13 & 0.47 & 0.33 \\
1980 & 1.45 & 0.29 & 0.51 & 0.33 & 0.13 & 0.53 & 0.33 \\
1990 & 1.90 & 0.48 & 0.61 & 0.42 & 0.14 & 0.64 & 0.44 \\
2001 & 1.92 & 0.39 & 0.75 & 0.51 & 0.18 & 0.65 & 0.46 \\
2007 & 2.33 & 0.43 & 1.00 & 0.74 & 0.18 & 0.71 & 0.44 \\
2019 & 2.56 & 0.90 & 0.75 & 0.49 & 0.20 & 0.76 & 0.48 \\
\hline
\end{tabular}

Source: FRED data and author's calculations.

mortgagees kept paying down. The net result was a fall in the household mortgage debt ratio, but that decline has now ended.

In sum, Table 1 provides supportive evidence for the narrative contained in Figure 9. Neither the narrative in Figure 9 nor the patterns in Table 1 look like 'steady-state' growth, which is the frame used in much theoretical analysis of financialization. Instead, the vampire squid economy looks unstable and needs repeated exogenous reset interventions. The instability is evident in the debt ratio trends, and the need for reset interventions following financial crises. Those interventions take the form of debt cancellation via default and resort to the balance sheets of the federal government and Federal Reserve. Evidence regarding the Federal Reserve's role is provided in the next section.

\section{THE ROLE OF CENTRAL BANKS IN THE VAMPIRE SQUID ECONOMY}

Central banks play a critical systemic role via their setting of the base interest rate, via underwriting financial asset prices, and via ensuring liquid financial markets. In the US, absent the Federal Reserve, it is likely the system would have crashed in '1929 Great Depression' fashion long ago.

The role of the Federal Reserve is illustrated in Figure 10, which shows how the central bank provides a backstop to the FIRE sector. The FIRE sector consists of multiple players (commercial banks, investment banks, insurance companies, mutual funds). Many of these players have been given increased ease of access to the Federal Reserve's balance sheet (that is, to funding from the Federal Reserve) over the past 15 years owing to the depth and breadth of the financial difficulties. However, the principal group the Federal Reserve engages with are the commercial banks. The left-hand circuit in Figure 10 shows the Federal Reserve backstopping the commercial banking system via its willingness to provide liquidity on an as-needed basis. Support has gone through two stages which correspond to the pre-QE and post-QE regimes. ${ }^{10}$

10. The major US investment banks (Bear Stearns, Lehman Brothers, Merrill Lynch) were essentially wiped out during the 2008 global financial crisis, and they are now part of commercial banks. Bear Stearns was taken over by JP Morgan; Merrill Lynch was taken over by Bank of America; Lehman Brothers was purchased by Barclays via a bankruptcy process; and Goldman Sachs converted itself to commercial bank status. Now, the entire sector (that is, the bulk of Wall Street) has access to the Federal Reserve's balance sheet, but that is hidden by the transactions that have placed those institutions within commercial banks. 


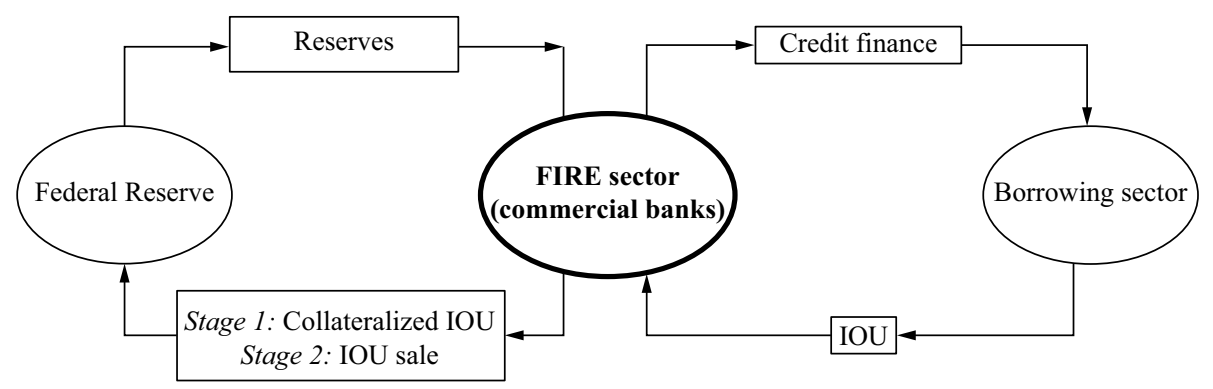

Figure 10 Financialization and the Federal Reserve (central banks)

The role of the Federal Reserve has evolved as the problems of the financialized system have become evident. Whereas Neoliberalism's goals of increasing the profit share and increasing the power of capital versus labor were explicit, the details of how the system works reflect an improvisational response to the emergent problems of increasing proclivity to instability and stagnation. ${ }^{11}$ The former has required the Federal Reserve to become the de facto guarantor of the financial system. The latter has it acting as macroeconomic resuscitator via a process of pushing asset prices ever higher.

As regards instability, the system has repeatedly shown itself fragile and unstable, both domestically and internationally. Moreover, that proclivity to instability emerged earlier in the process. In the US, there has been the 1987 stock market collapse, the 1998 Long Term Capital Management crisis, the 2001 technology stock market bubble, the 2007 house price bubble, and the 2008 global financial crisis. Internationally, there has been the 1990-1994 Swedish financial crisis, the 1992 Sterling crisis, the 1994 Mexico crisis, the 1997 East Asia crisis, the 1998 Russia crisis, the 1999 Brazil crisis, and the 2000 Argentina crisis. The IMF (Laeven and Valencia 2018) has documented that country systemic currency and banking crises also increased significantly in the Neoliberal era (post-1980).

As regards stagnation, that proclivity became especially clear after the 2008 global financial crisis when the US economy had difficulty picking itself off the floor despite massive financial assistance from fiscal policy and the Federal Reserve. However, the proclivity to stagnation was also visible long before to those open to seeing it. Thus, the Reagan business cycle (1981-1990) was followed by an extended weak recovery that coined the expression 'jobless recovery.' Similarly, though the 2001 recession was short and shallow, the recovery was slow to pick up and did not launch robustly until 2004.

After the 2008 global financial crisis, the recovery was so feeble it was labeled stagnation, and it also triggered a new set of policies that serve to divide the era of financialization. The first stage corresponds to the period 1980-2008. The second stage corresponds to 2009-today. The dividing mark is the global financial crisis of 2008.

11. The chief architect of the current system was Federal Reserve Chairman Alan Greenspan (1987-2005), who took over from Paul Volcker (1979-1987). In 1979, Volcker initiated the great disinflation by implementing high real interest rates. Volcker viewed high inflation as an existential threat, but recognized finance's inclinations to speculation and instability and was always a supporter of regulation. That was evidenced in the Dodd-Frank Act (2010), passed after the 2008 global financial crisis, in which he advocated for the 'Volcker rule' that stopped banks from engaging in short-term speculative trading on their own account. That contrasts with Greenspan, who was an avowed Neoliberal and partisan proponent of financial deregulation. 
The importance of that division is the first period was characterized by a robust process of AD generation, which gradually drained away under the influence of financialized Neoliberalism. The initially robust process of AD generation reflected the economy constructed during the post-World War II period of New Deal Keynesianism. The 1980s began the process of redistributing income upward and relying on borrowing and asset price inflation to drive AD growth. That process continued through the 1990s. If the economy stumbled, it could be picked up via a combination of increased budget deficits and lowered interest rates. At that stage, Neoliberalism had not yet undone the New Deal Keynesian system, and sector balance sheets were also still relatively unencumbered by debt.

By the early 2000s both of those features were fading. Two decades of financial Neoliberalism had delivered two decades of wage stagnation and rising income and wealth inequality, and there had also been a take-off in both household and corporate sector debt. Thus, despite that recession being short (nine months) and shallow, the economy struggled to recover from it and experienced an extended period of 'jobless recovery.' That jobless recovery required the Federal Reserve to keep interest rates ultra-low for an extended period through to 2004, and then only raise them slowly.

Those developments transformed the macroeconomic situation, and that transformation is evident in Federal Reserve policy. The process of transformation is obvious in Tables 2 and 3. Table 2 shows a brief history of the federal funds interest rate from 1981 to 2020. Table 3 shows the Federal Reserve's balance sheet liabilities as a share of GDP.

Table 2 shows that in the first stage of financialization (1980-2008) the Federal Reserve was able to lower interest rates every time the economy got into trouble, and thereby help jump-start economic recovery. It had lots of room to do this given the ultra-high interest rates in June 1981 which Chairman Volcker imposed to kill inflation in its tracks. From June 1981 to October 1985 rates trended down as the

Table 2 Brief history of the Federal Funds interest rate, June 1981-April 2020

\begin{tabular}{lcc}
\hline & High & Low \\
\hline June 1981 & $19.10 \%$ & - \\
October 1986 & - & $5.85 \%$ \\
April 1989 & $9.89 \%$ & - \\
December 1992 & - & $2.92 \%$ \\
November 2001 & $6.51 \%$ & - \\
May 2004 & - & $1.00 \%$ \\
July 2007 & $5.26 \%$ & - \\
December 2008 & - & $0.16 \%$ \\
April 2019 & $2.42 \%$ & - \\
April 2020 & - & $0.05 \%$ \\
\hline
\end{tabular}

Source: Board of Governors of the Federal Reserve.

Table 3 Federal Reserve total liabilities to GDP

\begin{tabular}{lcccccccc}
\hline & 1960 & 1970 & 1980 & 1990 & 2001 & 2007 & 2019 & 2020 \\
\hline Liabilities/GDP & 0.10 & 0.08 & 0.06 & 0.06 & 0.06 & 0.07 & 0.20 & 0.35 \\
\hline
\end{tabular}

Source: FRED data and author's calculations. 
Federal Reserve sought to help the economy out of the deep recession caused by Volcker's high interest rate policy. Once the economy was deemed to be closing in on full employment, rates were raised to 9.89 percent in April 1989. When recession struck in 1990 rates were reduced, hitting a low of 2.92 percent in December 1992. Thereafter they were slowly raised over the course of the 1990s expansion. That pattern of lowering and then raising was repeated in the 2001 recession and subsequent expansion.

Table 3 shows that during this period (1980-2008) the Federal Reserve's balance sheet was stable as measured against GDP. That changes after the 2008 global financial crisis. Interest rates are quickly lowered to near zero $(0.16)$, where they remain until January 2016 when a very gradual series of rate increases is initiated. With lower interest rates off the table, the Federal Reserve turns to using its balance sheet to save the system. That is evident in Table 3 which shows an explosion in the size of the balance sheet relative to GDP that has continued during the COVID-19 crisis. To save the system, the Federal Reserve is now monetizing the budget deficit (that is, buying newly issued government bonds), buying private sector papers and mortgage backed securities, and making liquidity available via both everyday standard facilities and temporary emergency crisis facilities.

At this stage, the vampire squid economy has embraced the Federal Reserve's balance sheet, and the process can be anticipated to continue and deepen in the next recession. Private sector balance sheets are heavily leveraged, leaving less to feed on and rendering privately issued liabilities at greater risk of default. The solution is to have the Federal Reserve's balance sheet come to the rescue by making direct loans to selected financial firms, buying up government debt, and buying new and existing private sector liabilities. That intervention buoys the price of financial assets and creates space for renewed private sector debt issuance.

Putting the Federal Reserve's balance sheet in play represents a significant ratcheting-up of the process. As of now, both the type of firm that can borrow from the Federal Reserve and the type of private sector liability that the Federal Reserve will purchase are limited. However, the Rubicon has been crossed and the principle of purchasing such liabilities has been established. At this stage, the allowable type can be expanded at the discretion of the Federal Reserve. Indeed, that expansion was evident in the response to the 2020 COVID-19 stock market crash, and it provides a precedent that will almost certainly be invoked in the next economic downturn.

\section{CHARACTERISTICS OF THE VAMPIRE SQUID ECONOMY: FRAGILITY AND PREFERENTIAL TREATMENT OF CAPITAL}

A distinctive feature of financialization is the creation of an economy that is characterized by fragility and preferential treatment of capital. The fragility was revealed in the 2008 global financial crisis, and again in a different manner in the COVID-19 crisis of 2020. Both Neoliberalism and financialization contribute to it.

Neoliberalism's contribution runs through globalization and the labor market. Thus, Neoliberal globalization has resulted in reliance on internationally extended supply chains which are prone to disruption. Labor markets also lack resilience owing to the shift to the 'hire and fire' model which makes job tenure fragile compared to the prior 'long-term relation' model. Technology has also played into that via promotion of the 'gig economy' in which workers are self-employed or informally employed. Under such conditions workers lack bargaining power, are released rapidly in 
downturns, and the social safety net is weak because workers are not connected to employers and steady work.

Financialization's contribution runs through debt, which is the vehicle for extracting value from households and corporations. That saddles sectors with over-leveraged balance sheets which lack a margin of safety, rendering agents prone to bankruptcy and inability to sustain economic activity in the event of negative shocks.

The system is characterized by asymmetry of exposure and preferential treatment of capital. Households are relatively unprotected in crises. In the US, they confront being laid off (hire and fire economy), low levels of unemployment insurance, and losing their health insurance. Households must meet their rent or be evicted, and meet their mortgage payments or be foreclosed upon.

In contrast capital has legally granted resilience whereby debt interest and rent continue to accrue. That is supplemented by policy which gives capital preferential protective treatment. 'Too big to fail' policy showers money on banks and important institutions on the basis of the position they occupy in the financial chain. Side by side, the Federal Reserve acts as a safety net for asset prices.

This system of a safety net for financial capital has been in the making for four decades, and it has increasingly displaced the post-World War II system that aimed to create a safety net for labor. The system puts a support under capital markets via the 'Greenspan put' (which has become the 'Bernanke put' and then the 'Powell put'), via $Q E$ which has the Federal Reserve buying mortgage-backed securities, via multiple lending facilities to different segments of the financial sector, and via commercial paper purchase facilities that support the non-financial corporate sector. Large corporations are de facto protected by the Federal Reserve's willingness to buy bonds and via its commercial paper facilities. Those purchases used to be restricted to investmentgrade bonds, but in the COVID-19 pandemic the standard was lowered to include junk bonds (BB and above). ${ }^{12}$

The Bank of Japan now purchases equities via exchange-traded funds (ETFs), and that can be expected to become part of the Federal Reserve's playbook in future. Having the Federal Reserve buy equities has been endorsed by former IMF Chief Economist Olivier Blanchard, and it has also been endorsed by elite Wall Street economists (Cecchetti et al. 2020). ${ }^{13}$ For many years there has also been talk of either the government investing social security funds in the stock market or privatizing social security. Both policies would massively increase demand for equities and increase equity prices, and they may resurface in a future crisis.

The Federal Reserve's systemic support for finance capital has always been present, but it moved into the open with the 2008 global financial crisis. The crisis playbook tacitly involved three steps. Step 1 was to stabilize the crisis by pointing the Federal Reserve's money hose at commercial banks and Wall Street, making sure they had

12. The support system also extends into the system of financial regulation. Thus, the SEC has acted to limit short selling in periods of equity market stress, but does not act to limit margin buying on the way up. The SEC has also experimented with a rule requiring limit buy orders be placed on the 5 cent mark as a way of concentrating buying power and preventing stock prices from falling.

13. For the past 40 years mainstream macroeconomics has increasingly emphasized the 'causal' importance of asset prices and the stock market for macroeconomic activity, and it is now an article of faith. The shift to emphasizing the stock market was shared by mainstream Keynesians, and an early important paper in shaping the new consensus was Blanchard (1981). Elite academic support for policies that bolster stock prices smacks of unconscious self-interest. The theoretical arguments run far ahead of the empirical evidence. 
unlimited liquidity at zero interest. Step 2 was foreclosure on households that were unable to meet their debts and mortgages to the banks. Step 3 had Wall Street buying up depressed assets and foreclosed properties using its access to zero interest money. The strategy was justified in the name of increasing the 'price of risky assets' so as to encourage risk-taking.

By putting the Federal Reserve's balance sheet in play, the 2008 global financial crisis response represented a significant ratcheting up of the financialization process. The 2020 COVID-19 crisis has prompted a further upward ratchet whereby a wider array of borrowers was given access to loans from the Federal Reserve, and a wider set of assets was deemed purchasable by the Federal Reserve. In the next crisis, those new criteria are likely to be the standard, and they may be further expanded to include equities.

Lastly, the weakened macroeconomic fundamentals that followed the 2001 recession obscure the picture. In the period through to 2000, central banks (including the Federal Reserve) imposed high real interest rates, which had the double effect of transferring income to bond holders and chilling the labor market and worker bargaining power. Since 2001, central banks have been forced into a different role of pushing ultra-low real interest rates as a way of reflating asset values and credit flows, which are essential to AD generation under financialization. That twist in policy posture has confused analytic understanding. It is not that central banks have discovered their social democratic inner selves. In both periods they have been agents of financial interests. However, changed economic fundamentals caused by financialization have required changed central bank policies to save the system from itself.

\section{THE TEFLON-COATED FED: STAGNATION AND THE DIFFICULTY OF EXPOSING THE SYSTEM}

The Federal Reserve is the critical institution sustaining financialization, without which it would implode. Yet calling the Federal Reserve on its role is extraordinarily difficult. One reason is the complicated macroeconomic picture (discussed above). A second reason is lack of analytic understanding owing to an intellectual hegemony that blocks seeing and speaking of the Federal Reserve in terms of financialization and its role therein.

Under Chairman Greenspan (1987-2005), the Federal Reserve was a champion of financial deregulation, Neoliberal globalization, the Neoliberal labor market flexibility agenda aimed at undercutting worker bargaining power, and the shareholder value maximization paradigm of corporate governance. Though subsequent Federal Reserve Chairpersons (Bernanke, Yellen, and Powell) have backed away from Greenspan's forthright Neoliberalism, the Federal Reserve remains committed to the overarching paradigm.

That commitment is evident in its persistent refusal to use policy instruments that can counter-cyclically target asset prices and credit excess. The Federal Reserve has rejected using margin requirements to limit debt-financed stock market speculation. It has also refused to adopt measures such as asset-based reserve requirements (ABRR) which can selectively raise the cost of credit to sectors and activities deemed overheated (Palley 2003; 2004).

Another clue regarding the Federal Reserve's role concerns its 'lender of last resort' activities. According to classic economic theory, which supposedly guides the Federal Reserve, a lender of last resort should require good collateral and charge a penalty 
interest rate. However, the Federal Reserve does neither. Instead, it has lent freely below market rates and accepted junk collateral (Humphrey 2010), which is consistent with the financialization hypothesis.

The defense of the Federal Reserve's supportive policies is that this is the right thing to do in a crisis. The argument is that not doing so would result in the financial system crashing and triggering a repeat of the 1929 Great Depression. Additionally, it is argued that the central bank is just engaging in counter-cyclical monetary policy. In the past, it would lower nominal interest rates. However, now that rates are at the zero lower bound, it is compelled to buy assets as the way to inject liquidity and create demand for risky assets.

That defense misrepresents by failing to speak about the 'system.' The repeated crises and the Federal Reserve's interventions take place within a system. That system encourages crisis and the Federal Reserve has been instrumental in creating the system (Palley 2005). The central bank has given intellectual support and policy legitimacy to the financialization paradigm, and has a fulcrum operational role. Simply claiming it is now doing its best to manage the economy is disingenuous to the point of dishonesty.

That said, the defense explains why it is so difficult to tag the Federal Reserve. Financialization has proven to deliver damaging social and economic outcomes. At this stage, the outcomes would likely be even worse without supportive policy actions. That reality protects the central bank from criticism, but it only does so by neglecting the issue of financialization.

Debate should be about the financialized system, in which case the Federal Reserve is implicated. However, mainstream economics lacks such a construct, and that lack obstructs debate and protects the Federal Reserve. ${ }^{14}$ It is hard to speak about something one does not have words for. That shows the importance of economic theory which determines what can be talked about.

Though unable to speak of financialization, all the manifest problems associated with it remain. That has compelled the mainstream to construct a new narrative of stagnation caused by an exogenously imposed collapse of animal spirits and the disappearance of investment opportunities. That explanation contrasts with the financialization narrative which provides a comprehensive economic account that explains developments over the past 40 years. The outlook for substantive change will depend, in part, on whether the exogenous stagnation or the financialization narrative prevails.

\section{LOCK-IN: TRAPPED BY THE TENTACLES OF THE VAMPIRE SQUID}

The difficulty in criticizing the Federal Reserve (and central banks in general), despite its fingerprints being all over financialization, speaks to the problem of policy lock-in (Palley 2017/2018). Despite being socially and economically dysfunctional, the financialization policy regime may endure because of obstructions which make it difficult and costly to change course.

Figure 11 identifies four mechanisms that serve to lock-in financialization. The first is labeled balance sheet lock-in. Financialization creates new financial facts in the form

14. Within mainstream macroeconomics the Federal Reserve is characterized as either a benevolent public servant or a self-interested bureaucracy. Neither fits the financialization profile, which is a system designed to benefit finance capital that the central bank is part of. Since that profile is off the mainstream macroeconomic table, mainstream macroeconomists are unable to engage with it. 


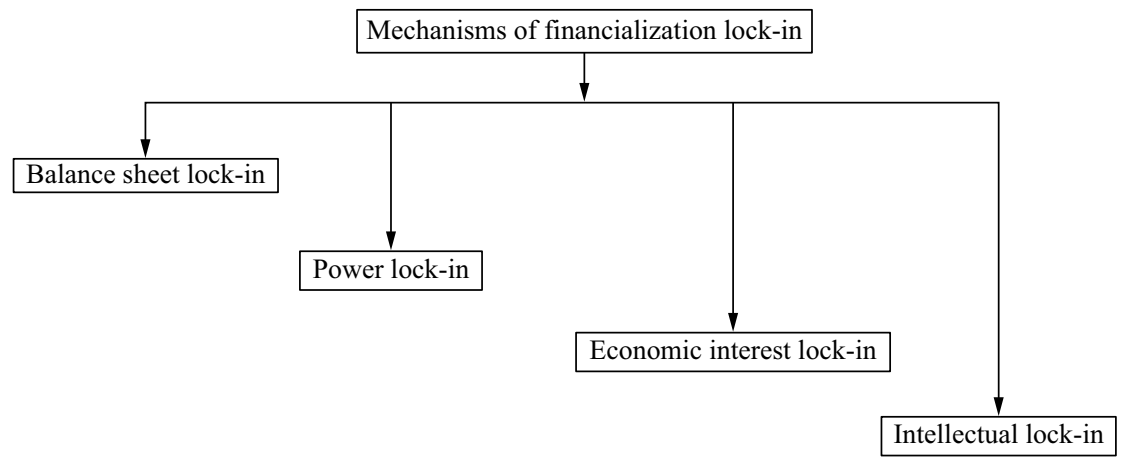

\section{Figure 11 Mechanisms of financialization lock-in}

of debts which load up sector balance sheets. Those debts constitute assets to the debt holders, and income streams are needed to service them. Attempts to reconstitute the economic system can have damaging effects, to the extent of even causing financial crisis. Restoring the wage share could make it difficult for firms to meet their debt obligations, with consequent effects on bond markets. Indebted firms would also find it difficult to raise finance, with potentially negative impacts on investment. A lower profit share would also reduce stock market values (about which more below). All of those forces make it hard to rebalance income distribution.

A similar logic holds for taxation. Having reduced corporate taxes, raising them could have major destabilizing consequences to the extent that balance sheets have been structured upon those tax rates and equities have been priced upon them. It is always difficult to transition from one system to another, and balance sheet lock-in makes it even more difficult.

A second mechanism of lock-in is power. Financialization has increased the economic power of Wall Street interests by vastly increasing their income and wealth relative to others. That income and wealth gives those interests the power to affect political and public opinion. At the most venal level, they can simply capture politicians and policymakers with promises of lucrative second and late-life careers. More generally, in a political system in which money is a critical necessity for electoral success, they can provide friendly candidates with the financing needed to win elections. In that fashion, wealth and income redistribution can lock-in financialization.

A third mechanism of lock-in is economic interest. Ironically, though financialization has hurt working families, it may also have built political support among some who have adopted it culturally and economically (Fligstein and Goldstein 2015). Economic policy has encouraged home-ownership, and it has also encouraged new retirement saving arrangements (for example, 401K plans and Individual Retirement Accounts) whereby people are direct investors in the stock market via defined contribution pension saving plans. As home-owners, people are supportive of policies (for example, tax-deductible interest, easier mortgage credit access, low interest rates) that inflate house prices. As direct investors, their interests get tied to the stock market and they may come to identify with financial interests. In effect, financialization may split people's identities, and workers may feel split regarding their roles as workers, home-owners, and investors. That splitting of economic identity can contribute politically to locking-in financialization.

The fourth mechanism is intellectual lock-in, which connects with the earlier discussion of the Teflon-coated Federal Reserve. Financialization has been intellectually 
justified by Neoliberal economics, which has provided the justification for the SVM model of corporate governance, financial deregulation, financial globalization, independent central banks, and the macroeconomics that justified high real interest rates in the 1980s and 1990s. Neoliberalism is now the hegemonic economic point of view, and that hegemony obstructs people from imagining alternative economic arrangements. In so doing, it tacitly locks-in existing arrangements.

In sum, the mechanisms of lock-in are varied and sophisticated. They can block the option of change from even being tabled, and can keep the system in place long after it has become economically dysfunctional. Moreover, political support for the system can come from those who are its victims, owing to the process transforming perceived economic interests.

\section{CONCLUSION: A DISQUIETING UNEXPLORED TERRAIN}

Both mainstream and heterodox economics recognize the enormous growth of the financial sector during the Neoliberal era. However, a striking difference between the two is the absence of an equivalent analytical construct to financialization within the former. That absence makes it difficult to talk about financialization within mainstream economics.

Heterodox economics interprets financialization through the lens of political economy, whereby the economy constitutes a political economic system in which politics and political interests are intrinsic and inescapably present. The economy is a contested terrain and its structure is constructed by dominant interests. In contrast, mainstream economics resists recognizing the inevitable politically constructed nature of both the economy and policy. Consequently, mainstream economics struggles with the essence of political economy, and that shows up in the absence of a construct akin to financialized Neoliberal capitalism.

At this stage, we are in a disquieting unexplored terrain. Mainstream economics explains current problems by appealing to the narrative of exogenous stagnation. It describes the Federal Reserve as a benevolent public servant that is trying to address the situation via the new policy modality of putting the Federal Reserve's balance sheet in the service of government and financial markets. That modality has the Federal Reserve using its balance sheet to fill the AD gap by financing large budget deficits. The Federal Reserve's balance sheet is also being used to support asset prices via purchases of mortgage-backed securities, the promise to lend money freely in a liquidity crisis, and the 'unspoken' promise to buy equities in the event of a meltdown. For mainstream economists the only fear is some form of surprise Monetarist inflation that triggers interest rate re-rating, with consequent negative effects for asset prices.

The financialization perspective is more complicated and political. It explains current problems as the product of contradictions whereby financialization undermines the AD generation process. The open question is how long policy can use the Federal Reserve's balance sheet to patch those contradictions.

The contradictions are both economic and political. First, inflating asset prices carries classic bubble risks of its own. The higher prices get, the more they are at risk from either an evaporation of sentiment or a change in underlying economic fundamentals. Second, there is an increasing political imperative to rebalance income distribution, which will require increasing the wage share. That political imperative poses an inflation risk of its own, and it also stands to undercut asset prices with consequent financial instability implications. Additionally, it stands to provoke resistance from Wall Street interests, introducing another source of uncertainty. 
The implication is that economic policy confronts being pulled in contradictory directions. On the one hand, the Federal Reserve is committed to maintaining (and even increasing) asset prices. On the other hand, broader political and economic policy concerns require increasing the wage share, which undercuts asset prices. Deficitfinanced fiscal policy can help sustain $\mathrm{AD}$, but it cannot resolve this contradiction and fiscal policy will struggle to offset the impact of credit markets seizing up.

\section{REFERENCES}

Barba, A. and M. Pivetti (2009), 'Rising household debt: its causes and macroeconomic implications: a long-period analysis,' Cambridge Journal of Economics, 33, 113-137.

Bebchuk, L. and J. Fried (2004), Pay Without Performance: The Unfulfilled Promise of Executive Compensation, Cambridge, MA: Harvard University Press.

Blanchard, O. (1981), 'Output, the stock market, and interest rates,' American Economic Review, 71(1), 132-143.

Bronars, S.G. and D.R. Deere (1991), 'The threat of unionization, the use of debt, and the preservation of shareholder wealth,' Quarterly Journal of Economics, CVII(February), 231-254.

Cecchetti, S., M. Feroli, A.K. Kayshap, C.L. Mann, and K. Schoenholtz (2020), 'Monetary policy in the next recession?,' CEPR Discussion Paper No DP15365.

Cynamon, B.Z. and S.M. Fazarri (2008), 'Household debt in the consumer age: source of growth - risk of collapse,' Capitalism and Society, 3(2), 1-32.

Cynamon, B.Z. and S.M. Fazarri (2016), 'Inequality, the Great Recession and slow recovery,' Cambridge Journal of Economics, 40(2), 383-399.

Duesenberry, J.S. (1949), Income, Saving and the Theory of Consumption Behavior, Cambridge, MA: Harvard University Press.

Dünhaupt, P. (2016), 'The effect of financialization on labor's share of income,' Cambridge Journal of Economics, 41, 283-306.

Dutt, A.K. (2006), 'Maturity, stagnation and consumer debt: a Steindlian approach,' Metroeconomica, 57(July), 339-364.

Epstein, G. (2004), 'Introduction,' in G. Epstein (ed.), Financialization and the World Economy, Cheltenham, UK and Northampton, MA: Edward Elgar Publishing, pp. 3-16.

Epstein, G. (2015), 'Financialization: there's something happening here,' PERI Working Paper 394, UMass Amherst, Amherst, MA.

Epstein, G. and A. Jayadev (2005), 'The rise of rentier incomes in OECD countries: financialization, central bank policy, and labor solidarity,' in G. Epstein (ed.), Financialization and the World Economy, Cheltenham, UK and Northampton, MA: Edward Elgar Publishing, pp. $46-76$.

Fligstein, N. and A. Goldstein (2015), 'The emergence of a finance culture in American households, 1989-2007,' Socio-Economic Review, 13, 575-601.

Frank, R.H. (1985), Choosing the Right Pond: Human Behavior and the Quest for Status, New York: Oxford University Press.

Frank, R.H., A.S. Levine, and O. Dijk (2014), 'Expenditure cascades,' Review of Behavioral Economics, 1, 55-73.

Friedman, M. (1970), 'The social responsibility of business is to increase its profits,' New York Times, 13 September.

Glick, R. and M. Hutchinson (1999), 'Banking and currency crises: how common are twins?,' Pacific Basin Working Papers Series PB99-07, Center for Pacific Basin Monetary and Economic Studies, Research Department, Federal Reserve Bank of San Francisco.

Graebner, D. (2011), Debt: The First 5000 Years, London: Melville Press.

Greenwood, R. and D. Scharfstein (2013), 'The growth of finance,' Journal of Economic Perspectives, 27(2), 3-28.

Hein, E. (2012), The Macroeconomics of Finance-Dominated Capitalism and its Crisis, Cheltenham, UK and Northampton, MA: Edward Elgar Publishing. 
Hein, E. (2015), 'Finance-dominated capitalism and the re-distribution of income: a Kaleckian perspective,' Cambridge Journal of Economics, 39, 907-934.

Hein, E. and T. van Treeck (2010), 'Financialization in post-Keynesian models of distribution and growth: a systematic review,' in M. Setterfield (ed.), Handbook of Alternative Theories of Economic Growth, Cheltenham, UK and Northampton, MA: Edward Elgar Publishing, pp. 277-292.

Hudson, M. (2021), 'Rent-seeking and asset-price inflation: a total-returns profile of economic polarization in America,' Review of Keynesian Economics, 9(4), 435-460.

Humphrey, T. (2010), 'Lender of last resort: what it is, whence it came, and why the Fed isn't it,' Cato Journal, 30(2), 333-364.

Jarsulic, M. (2010), Anatomy of a Financial Crisis: A Real Estate Bubble, Runaway Credit Markets, and Regulatory Failure, New York: Palgrave Macmillan.

Jayadev, A. (2007), 'Capital account openness and the labor share of income,' Cambridge Journal of Economics, 31, 423-433.

Jensen, M.J. and W.H. Meckling (1976), 'Theory of the firm: managerial behavior, agency costs and ownership structure,' Journal of Financial Economics, 3, 305-360.

Kim, Y.K., G.T. Lima, and M. Setterfield (2019), 'Political aspects of household finance: debt, wage bargaining, and macroeconomic (in)stability,' Journal of Post Keynesian Economics, 42(1), 16-38.

Kohler, K., A. Guschanski, and E. Stockhammer (2019), 'The impact of financialization on the wage share: a theoretical clarification and empirical test,' Cambridge Journal of Economics, 43, 937-974.

Krippner, G. (2005), 'The financialization of the American economy,' Socio-Economic Review, 3(2), 173-208.

Laeven, L. and F. Valencia (2018), 'Systemic banking crises revisited,' IMF Working Paper No 18/206, Strategy, Policy, and Review Department, Washington, DC: International Monetary Fund.

Lapavitsas, C. (2009), 'Financialised capitalism: crisis and financial expropriation,' Historical Materialism, 17, 114-148.

Lazonick, W. (2014), 'Profits without prosperity,' Harvard Business Review, September, available at: https://hbr.org/2014/09/profits-without-prosperity.

Lazonick, W. and M. O'Sullivan (2000), 'Maximizing shareholder value: a new ideology for corporate governance,' Economy and Society, 29, 13-35.

Lysandrou, P. (2017), 'The colonization of the future: an alternative view of financialization and its portents,' Journal of Post Keynesian Economics, 39(4), 444-472.

Minsky, H.P. (1992a), 'Schumpeter and finance,' Hyman P. Minsky Archive, Paper 280, Bard Digital Commons, Bard College, New York.

Minsky, H.P. (1992b [1993]), 'The financial instability hypothesis,' Working Paper No 74, The Jerome Levy Economics Institute of Bard College, New York (published in P. Arestis and M. Sawyer (eds), Handbook of Radical Political Economy, Aldershot, UK and Brookfield, VT: Edward Elgar Publishing).

Orhangazi, Ö. (2008a), Financialization and the US Economy, Cheltenham, UK and Northampton, MA: Edward Elgar Publishing.

Orhangazi, Ö. (2008b), 'Financialization and capital accumulation in the non-financial sector: a theoretical and empirical investigation on the US economy: 1973-2003,' Cambridge Journal of Economics, 32, 863-886.

Palley, T.I. (1994), 'Debt, aggregate demand, and the business cycle: an analysis in the spirit of Kaldor and Minsky,' Journal of Post Keynesian Economics, 16(Spring), 371-390.

Palley, T.I. (1997a), 'Endogenous money and the business cycle,' Journal of Economics, 65, 133-149.

Palley, T.I. (1997b), 'Managerial turnover and the theory of short termism,' Journal of Economic Behavior and Organization, 32, 547-557.

Palley, T.I. (2003), 'Asset price bubbles and the case for asset based reserve requirements,' Challenge, 46(May-June), 53-72.

Palley, T.I. (2004), 'Asset based reserve requirements: reasserting domestic monetary control in an era of financial innovation and instability,' Review of Political Economy, 16(January), 43-58. 
Palley, T.I. (2005), 'The questionable legacy of Alan Greenspan,' Challenge, 48(6), 17-31.

Palley, T.I. (2007 [2008]) 'Financialization: what it is and why it matters,' Levy Economics Institute of Bard College Working Paper No 525, Bard College, New York (published in E. Hein, T. Niechoj, P. Spahn, and A. Truger (eds), Finance-Led Capitalism? Macroeconomic Effects of Changes in the Financial Sector, Marburg: Metropolis-Verlag, pp. 29-60).

Palley, T.I. (2009), 'The macroeconomics of financialization: a stages of development approach,' Ekonomiaz Revista Vasca de Economia, 72, 34-53.

Palley, T.I. (2010a), 'The limits of Minsky's financial instability hypothesis as an explanation of the crisis,' Monthly Review, April, 28-43.

Palley, T.I. (2010b), 'The relative permanent income theory of consumption: a synthetic Keynes-Duesenberry-Friedman model,' Review of Political Economy, 1(January), 41-56.

Palley, T.I. (2010c), 'Inside debt and economic growth: a Cambridge-Kaleckian analysis,' in M. Setterfield (ed.), The Alternative Handbook of Economic Growth, Cheltenham, UK and Northampton, MA: Edward Elgar Publishing, pp. 293-308.

Palley, T.I. (2011), 'A theory of Minsky super-cycles and financial crises,' Contributions to Political Economy, 30(1), 31-46.

Palley, T.I. (2012), From Financial Crisis to Stagnation: The Destruction of Shared Prosperity and the Role of Economics, Cambridge, UK: Cambridge University Press.

Palley, T.I. (2013), Financialization: The Macroeconomics of Finance Capital Domination, New York: Palgrave Macmillan.

Palley, T.I. (2017/2018), 'A theory of economic policy lock-in and lock-out via hysteresis: rethinking economists' approach to economic policy,' Economics: The Open-Access, Open-Assessment E-Journal, 11, 1-18.

Palley, T.I. (2018), 'Three globalizations, not two: rethinking the history and economics of trade and globalization,' European Journal of Economics and Economic Policy, 15(2), 174-192.

Palley, T.I. (2019), 'Central bank independence: a rigged debate based on false politics and economics,' Investigacion Economica, 78(310), 67-102.

Pérez Caldentey, E. and M. Vernengo (2021), 'Financialization, premature deindustrialization, and instability in Latin America,' Review of Keynesian Economics, 9(4), 493-511.

Posen, A. (2007), 'Don't worry about U.S. mortgages,' Welt am Sonntag, 12 April, available at: https://www.piie.com/commentary/op-eds/dont-worry-about-us-mortgages.

Ross, S. (1973), 'The economic theory of agency: the principal's problem,' American Economic Review, 63(2), 134-139.

Ryoo, S. and P. Skott (2008), 'Financialization in Kaleckian economies with and without labor constraints,' Intervention, 5(2), 357-386.

Sawyer, M. (2013), 'What is financialization?,' International Journal of Political Economy, 42(4), 5-18.

Stockhammer, E. (2004), 'Financialization and the slowdown of accumulation,' Cambridge Journal of Economics, 28, 719-741.

Stockhammer, E. (2015), 'Rising inequality as a root cause of the present crisis,' Cambridge Journal of Economics, 39, 935-958.

Stockhammer, E. (2017), 'Determinants of the wage share: a panel analysis of advanced and developing economies,' British Journal of Industrial Relations, 55, 3-33.

Tori, D. and Ö. Onaran (2017), 'The effects of financialization and financial development on investment: evidence from firm level data in Europe,' Greenwich Papers in Political Economy, No 44, London: University of Greenwich.

Ungarino, R. (2021), 'Here are 9 fascinating facts to know about Blackrock, the world's largest asset manager,' Business Insider, 10 June, available at: https://www.businessinsider.com/ what-to-know-about-blackrock-larry-fink-biden-cabinet-facts-2020-12? $r=U S \& I R=T$.

Wray, L.R. (2009), 'Money manager capitalism and the global financial crisis,' Real World Economics Review, 51(December), 55-69. 